\title{
Response of acid mobilization of iron-containing mineral dust to improvement of air quality projected in the future
}

\author{
A. Ito ${ }^{1}$ and $\mathbf{L} \cdot \mathbf{X u}^{2, *}$ \\ ${ }^{1}$ Research Institute for Global Change, JAMSTEC, Yokohama, Kanagawa, 236-0001, Japan \\ ${ }^{2}$ Department of Atmospheric, Oceanic and Space Sciences, University of Michigan, Ann Arbor, MI 48109-2143, USA \\ *now at: Scripps Institution of Oceanography, University of California San Diego, La Jolla, CA 92093, USA
}

Correspondence to: A. Ito (akinorii@jamstec.go.jp)

Received: 21 August 2013 - Published in Atmos. Chem. Phys. Discuss.: 31 October 2013

Revised: 17 February 2014 - Accepted: 23 February 2014 - Published: 7 April 2014

\begin{abstract}
Acidification of dust aerosols may increase aerosol iron $(\mathrm{Fe})$ solubility, which is linked to mineral properties. Combustion aerosols can also elevate aerosol iron solubility when aerosol loading is low. Here, we use an atmospheric chemical transport model to investigate the deposition of filterable iron and its response to changes in anthropogenic emissions of both combustion aerosols and precursor gases. By introducing three classes of iron-containing minerals into the detailed aerosol chemistry model, we provide a theoretical examination of the effects of different dissolution behaviors on the acid mobilization of iron. Comparisons of modeled Fe dissolution curves with the measured dissolution rates for African, east Asian, and Australian dust samples show overall good agreement under acidic conditions. The improved treatment of Fe in mineral dust and its dissolution scheme results in reasonable predictive capability for iron solubility over the oceans in the Northern Hemisphere. Our model results suggest that the improvement of air quality projected in the future will lead to a decrease of the filterable iron deposition from iron-containing mineral dust to the eastern North Pacific due to less acidification in Asian dust, which is mainly associated with the reduction of nitrogen oxides $\left(\mathrm{NO}_{\mathrm{x}}\right)$ emissions. These results could have important implications for iron fertilization of phytoplankton growth, and highlight the necessity of improving the process-based quantitative understanding of the response of the chemical modification in iron-containing minerals to environmental changes.
\end{abstract}

\section{Introduction}

Bioavailable iron ( $\mathrm{Fe}$ ) is an essential nutrient for primary production in marine ecosystems. Mineral dust and combustion aerosols are a key external source of bioavailable iron to surface waters in open oceans (Raiswell and Canfield, 2012; Schulz et al., 2012). Modeling studies have examined the impact of land-use change, climate change and $\mathrm{CO}_{2}$ increases on future dust deposition, but future impacts of environmental changes in air quality on bioavailable iron inputs to oceans have not been considered (Mahowald et al., 2009). The coatings of dust with soluble materials (e.g., sulfate and nitrate) may enhance their dry and wet scavenging over polluted areas and thus reduce the deposition of iron to the remote oceans (e.g., Fan et al., 2004). Therefore, the reduction of air pollutant gases may decrease the deposition of iron over polluted areas and thus increase its deposition over the remote oceans. More importantly, the response of bioavailable iron deposition to environmental changes is not well understood. The measurements for potentially bioavailable iron are commonly made following filtration through 0.2 or $0.45 \mu \mathrm{m}$ filters. We use the term "filterable" iron here for potentially bioavailable iron in all sizes of mineral dust passing the filters in order to emphasize that this fraction includes ferrihydrite colloids, nanoparticles and aqueous species (Raiswell and Canfield, 2012). Studies using "ultrafiltration" in addition to a membrane pore diameter of $\approx 0.025 \mu \mathrm{m}$ are assumed to measure dissolved iron only (Deguillaume et al., 2005). With decreasing crystal sizes, the dissolved iron fraction (i.e., the fraction of total aerosol iron that passes through $0.025 \mu \mathrm{m}$ filters) of iron oxides increases and can approach 
the dissolved iron fraction of ferrihydrite (Kraemer, 2004). In this manuscript we use the terms iron solubility for the filterable iron case and dissolved iron fraction for the dissolved iron case. Large uncertainties in the aerosol iron solubility (i.e., the fraction of total aerosol iron that passes through 0.2 or $0.45 \mu \mathrm{m}$ filters) hamper accurate simulations of the effects of changes in iron deposition on marine productivity and climate (Mahowald, 2011).

Higher iron solubility is often observed for iron-containing aerosols at lower loading than dust aerosols near the source regions (Chen and Siefert, 2004; Baker and Jickells, 2006; Sholkovitz et al., 2012). Two prominent hypotheses, which we explore to explain the enhanced iron solubility, are atmospheric processing and source composition (Mahowald et al., 2009; Baker and Croot, 2010). Zhuang et al. (1992) have proposed that a strong acidity in aerosols can eventually lead to the production of bioavailable iron from mineral dust. Global transport models have used a parameterization of the Fe dissolution rate in dust to fit the observations of iron solubility (Hand et al., 2004; Fan et al., 2006; Han et al., 2012). A chemical transport model that implemented an explicit iron dissolution scheme of hematite in dust aerosols suggests that doubling $\mathrm{SO}_{2}$ emissions can induce a significant increase in acid mobilization of iron and deposition to the remote Pacific (13\% on average) (Meskhidze et al., 2005; Solmon et al., 2009). In our atmospheric chemistry transport model simulations, the inclusion of the alkaline minerals (e.g., $\mathrm{CaCO}_{3}$ and $\mathrm{MgCO}_{3}$ ) in aqueous chemistry substantially limits the iron dissolution of hematite in dust aerosols during the long-range transport to the North Pacific Ocean (Ito and Feng, 2010). These model simulations might highlight the importance of atmospheric processing of iron-containing aerosols emitted from soils, but responses of iron mobilization to changes in anthropogenic emissions largely remain uncertain.

Iron-bearing minerals include crystalline iron oxides (e.g., hematite and goethite), clay minerals (e.g., illite, kaolinite, and smectite), ferrihydrite, and other poorly crystalline iron phases (Shi et al., 2012). Here, we use iron oxides as a general term for the various iron oxide, iron oxyhydroxide and amorphous iron hydroxide phases. The dissolution of iron under acidic conditions from soils and dusts occurs in two distinct stages over timescales of hours and weeks (Desboeufs et al., 1999; Mackie et al., 2005; Cwiertny et al., 2008; Shi et al., 2011a). Accordingly, iron in dust can be partitioned into three classes broadly defined in terms of dissolution rates: readily released, slowly released and refractory. Since the fractions of readily and slowly released iron in dust aerosols may differ among different source regions, understanding the extent to which dissolution of iron from these different regions occurs would better inform predictions of the supply of bioavailable iron to the ocean (Mackie et al., 2005; Shi et al., 2011a).

Model studies have applied different dissolution rates of minerals, different concentrations of minerals, and different contents of $\mathrm{Fe}$ in minerals to estimate the amount of iron dissolved from different types of minerals (i.e., hematite, illite and smectite) (Ito and Feng, 2010; Johnson et al., 2010; Ito, 2012). However, the calculated $\mathrm{Fe}$ dissolution rates are much slower than those obtained from the laboratory experiments for different dust source samples (Mackie et al., 2005; Shi et al., 2011a). In addition to the variables considered in the models, diverse mineral source materials, different acid types, and photochemical reactions affect $\mathrm{Fe}$ dissolution rates (Cwiertny et al., 2008; Journet et al., 2008; Fu et al., 2010). The faster dissolution of iron in the laboratory experiments may be associated with iron nanoparticulate $(<0.1 \mu \mathrm{m})$ and poorly crystalline iron oxides on aluminosilicate particles (Shi et al., 2011a; Raiswell and Canfield, 2012). The dissolution of iron oxyhydroxide, goethite $(\alpha-\mathrm{FeOOH})$, depends critically on the size of the particles and type of acids (Rubasinghege et al., 2010). The differences in Fe dissolution of different sizes of hematite nanoparticle aggregates can be ascribed to differences in the fraction of aggregate surface area that is reactive (Lanzl et al., 2012). The solubility of iron oxides is also enhanced by the formation of soluble $\mathrm{Fe}$ complexes in high concentrations of oxalate in solution (Pehkonen et al., 1993; Xu and Gao, 2008; Cwiertny et al., 2009; Paris et al., 2011; Lanzl et al., 2012). If the oxalate-promoted iron dissolution scheme is applied to mineral aerosols, the effect of organic acids on iron dissolution could be a potentially important process to be considered in global models (Luo et al., 2005; Luo and Gao, 2010; Johnson and Meskhidze, 2013). If the oxalate significantly promotes the iron dissolution, high iron solubility would be observed during high oxalate concentration. However, it is inherently difficult to substantiate the causation based on filed measurements, because high oxalate concentration and iron solubility are likely associated with anthropogenic emission sources (Takahashi et al., 2013; Wozniak et al. 2013). Besides acid mobilization in the aqueous phase, enhanced dissolution of iron oxides in ice is proposed as a pathway of bioavailable iron production (Kim et al., 2010; Jeong et al., 2012). However, analysis of snow samples collected in Japan suggested relatively low iron solubility of Asian dust (0.20-0.57\%) (Ooki et al., 2009). Atmospheric chemical transport models are useful to understand the effect of each factor involved in the dissolution process and to validate the laboratory results for their applications under ambient atmospheric conditions.

The initial composition of the aerosol materials can be a critical control on the observed high iron solubility, especially when considering the combustion aerosols (Chuang et al., 2005; Sedwick et al., 2007). The emission of aerosols from combustion processes could be the most important contributor to the elevated iron solubility values observed at low aerosol iron loadings over the oceans (Sholkovitz et al., 2012). Analysis of single iron-containing particles combined with bulk iron solubility measurements sampled from a variety of emission sources and urban sites showed a positive relationship between iron solubility and the sulfur content (Oakes et al., 2012). Iron in oil fly ash is mainly present 
as ferric sulfate salt $\left(\mathrm{Fe}_{2}\left(\mathrm{SO}_{4}\right)_{3} \cdot 9\left(\mathrm{H}_{2} \mathrm{O}\right)\right)$ and nanoparticles, and thus is highly soluble (Schroth et al., 2009; Fu et al., 2012). These species might be formed via high-temperature combustion followed by a sulfuric acid condensation before filtration (Sippula et al., 2009). Fly ash could be emitted with a large amount of acidic pollutants and thus mobilized due to acidification. Since the plume chemistry for the co-emitted species is a sub-grid-scale phenomenon in our coarse-scale model, we simply prescribed the Fe solubility for each combustion aerosol (i.e., oil fly ash, coal fly ash, and biomass burning aerosols) when it is emitted (Ito and Feng, 2010; Ito, 2012, 2013). Previous global model studies have demonstrated that the contributions of combustion aerosols to filterable $\mathrm{Fe}$ deposition are highly sensitive to uncertainties in iron solubility (Luo et al., 2008; Ito, 2012). Our atmospheric chemistry transport model suggested that oil combustion from shipping mainly contributed to high iron solubility $(>10 \%)$ at low iron loading $\left(<100 \mathrm{ng} \mathrm{m}^{-3}\right)$ over open oceans, rather than the other combustion sources from continental industrialized regions (Ito, 2013). The model results further suggested that shipping in 2100 contribute $30-60 \%$ of the filterable iron deposition over the high-latitude North Atlantic and North Pacific (Ito, 2013).

Here, we use the global chemical transport model to investigate the effect of changes in anthropogenic sources of combustion aerosols and precursor gases on filterable iron input to the oceans. In previous studies, we used the model to investigate several factors associated with uncertainties in future projections of the filterable iron deposition from variations in the dust alkalinity (Ito and Feng, 2010), the intensity of forest fires (Ito, 2011), the iron solubility in biomass burning aerosols (Ito, 2012), the dust size distribution (Ito et al., 2012), and the iron solubility of fossil fuel combustion aerosols (Ito, 2013). Determination of iron dissolution for different types of minerals requires two key parameters of Fe dissolution rate and mineral concentration. We examine Fe dissolution rates for the readily released iron in dust under acidic conditions that are 1-2 orders of magnitude larger than those for more crystalline and larger-size iron oxides, based mainly on the laboratory experiments for specific mineral samples (Journet et al., 2008; Shi et al., 2011b) and for soil and dust samples (Mackie et al., 2005; Shi et al., 2011a). Here, the readily released iron is defined as rapidly released iron from mineral dust under highly acidic condition and may be associated with aggregates of iron nanoparticulate and poorly crystalline iron oxides. We use both an updated version of the chemical transport model (Xu and Penner, 2012) and a mineralogical database (Nickovic et al., 2012). To assess model assumptions for iron dissolution, the calculated iron solubility is evaluated against a compilation of measurements from cruise ships over the oceans in the Northern Hemisphere (Chen and Siefert, 2004; Baker et al., 2006a, b; Buck et al., 2006, 2010; Sedwick et al., 2007; Aguilar-Islas et al., 2010; Hsu et al., 2010; Witt et al., 2010; Sholkovitz et al., 2012). The model provides the filterable iron supply from dust sources to the oceans in association with future changes in air quality based on the Intergovernmental Panel on Climate Change (IPCC) Representative Concentration Pathway (RCP) 4.5 emission scenario (Thomson et al., 2011). Section 2 describes the modeling methods and the numerical experiments that were performed. The sensitivity of iron solubility and filterable iron deposition in different simulations as well as comparisons of the model with observations of iron solubility are conducted in the Sect. 3 followed by the summary of our findings in the Sect. 4.

\section{Model approach}

\subsection{Model description}

The global chemical transport model used in this study is a version of the Integrated Massively Parallel Atmospheric Chemical Transport (IMPACT) model that includes aerosol chemistry (Rotman et al., 2004; Liu et al., 2005; Feng and Penner, 2007; Ito and Feng, 2010; Ito, 2011, 2012, 2013; Ito et al., 2012; Xu and Penner, 2012). The model simulates the emissions, chemistry, transport, and deposition of major aerosol species, including mineral dust, black carbon, particulate organic matter, particulate inorganic matter, sulfate, nitrate, ammonium and sea salt aerosols, and their precursor gases. The model is driven by assimilated meteorological fields from the Goddard Earth Observation System (GEOS) of the NASA Global Modeling and Assimilation Office (GMAO). The GEOS-5 meteorological fields have been archived with a $6 \mathrm{~h}$ temporal resolution ( $3 \mathrm{~h}$ for surface quantities and mixing depths) on a horizontal resolution of $0.5^{\circ} \times 0.666^{\circ}$ with 72 vertical layers. Simulations have been performed at a horizontal resolution of $2.0^{\circ} \times 2.5^{\circ}$ with 59 vertical layers from December 2003 to December 2004. We analyzed the simulation results that used the meteorological fields for the year 2004.

In our standard model (Experiment 1), the filterable $\mathrm{Fe}$ concentration in aerosols depends on the source material (i.e., soil or fly ash), mineralogy (e.g., hematite, illite and smectite), and acidity of mineral dust. The emission data sets for combustion-generated iron such as those from fossil fuel combustion and biomass burning are taken from the emission inventory described by Ito (2013). We use the arithmetic mean of the Fe content in combustion aerosol particles (Ito and Feng, 2010). The net emission factors of iron for each category of fossil fuel use are listed in Tables 1 and 2 of Ito (2013). We prescribe iron solubility in oil combustion aerosols (79\%) (Schroth et al., 2009), coal combustion aerosols (11\%) (Desboeufs et al., 2005; Chen et al., 2012), and biomass burning aerosols (18\%) (Bowie et al., 2009). Iron loadings as well as the filterable iron loadings of fossil fuel combustion aerosols are constrained in our model by observations (Ito, 2013). 
Emissions of dust are calculated online, based on the surface wind speed and soil wetness from the GEOS-5 meteorological fields (Ito et al., 2012). The size-resolved dust emission scheme is based on that developed by Ginoux et al. (2001) and is revised using the size distribution at emission of Kok (2011). Mineral dust and sea salt aerosols are predicted in four size bins (radius: $<0.63,0.63-1.25,1.25-$ 2.5, and 2.5-10 $\mu \mathrm{m})$. Carbonaceous aerosols are composed of black carbon and organic matter, while inorganic matter (e.g., iron) from combustion sources is treated as a separate tracer (Ito and Feng, 2010). An online sulfur model is applied to predict the concentrations of sulfur dioxide $\left(\mathrm{SO}_{2}\right)$, sulfate aerosol $\left(\mathrm{SO}_{4}^{2-}\right)$ for the nucleation (radius $<0.05 \mu \mathrm{m}$ ) and accumulation (radius $>0.05 \mu \mathrm{m}$ ) modes, hydrogen peroxide $\left(\mathrm{H}_{2} \mathrm{O}_{2}\right.$ ), and dimethyl sulfide (DMS) (Liu et al., 2005). Sulfate may also become coated on other aerosol types by condensation, coagulation, and through the formation of sulfate in drops (Herzog et al., 2004). An online nitrogen chemistry model is applied to predict the concentrations of $\mathrm{NO}_{\mathrm{x}}(\equiv \mathrm{NO}$ $+\mathrm{NO}_{2}$ ), $\mathrm{NO}_{3}, \mathrm{~N}_{2} \mathrm{O}_{5}$, and $\mathrm{HNO}_{3}$ (Feng and Penner, 2007). Aerosol $\mathrm{pH}$ is calculated from the internal particle composition $\left(\mathrm{H}^{+}\right.$and $\left.\mathrm{H}_{2} \mathrm{O}\right)$ for each size bin by the thermodynamic equilibrium module (Jacobson, 1999). Activity coefficients correct for the deviation from ideal behavior of a solution. The thermodynamic equilibrium module includes interactive computation of mean mixed activity coefficients. The activity of ion pair with hydrogen ions is considered in solving each equilibrium equation.

\subsection{Aging process of mineral dust and combustion aerosols}

The chemical composition of mineral dust and combustiongenerated aerosols can change dynamically from that in the originally emitted aerosols due to reactions with gaseous species. A number of revisions to the chemistry from our previous version (Ito, 2013) were made for the present study. Here, five types of aerosols (i.e., dust, sulfate, carbonaceous aerosols from fossil fuel combustion, carbonaceous aerosols from biomass burning, and sea salt) were assumed to be externally mixed in each size bin for the computation of aerosol chemistry, while nitrate and ammonium were internally mixed within each aerosol type (Xu and Penner, 2012). The simulation of externally mixed aerosols is important because the gas-phase precursors are allowed to be separately taken up by the urban-derived pollution particles, thus limiting the formation of sulfate, ammonium and nitrate on dust particles (Song et al., 2007). The dynamic aerosol treatment for sulfate aerosol and its interaction with non-sulfate aerosol components follows that developed by Herzog et al. (2004). The surface coating of sulfate on dust, combustion-generated aerosols and sea salt occurs as a result of the condensation of sulfuric acid gas on their surfaces, coagulation with pure sulfate aerosol, and formation in aqueous reactions within cloudy regions of the atmosphere (Liu et al., 2005). The het- erogeneous uptake of nitrate $\left(\mathrm{NO}_{3}^{-}\right)$and ammonium $\left(\mathrm{NH}_{4}^{+}\right)$ by each aerosol for each size bin is interactively simulated in the model following a hybrid dynamical approach (Feng and Penner, 2007). The thermodynamic equilibrium module solves any number of aqueous-ion, aqueous-solid, ion-ion, ion-solid, solid-solid, gas-solid, gas-aqueous, and gas-ion equilibrium equations simultaneously for the fine mode (radius $<0.63 \mu \mathrm{m}$ ), while a dynamic method is adopted to calculate the mass transfer-limited aerosol concentrations in larger particles (radius $>0.63 \mu \mathrm{m}$ ).

The aging of dust and combustion-generated aerosols from hydrophobic to hydrophilic enhances their dry and wet deposition. Dry deposition of aerosol particles uses a resistancein-series parameterization following Zhang et al. (2001). Gravitational settling is also taken into account. Hygroscopic growth of mineral dust, combustion-generated aerosols and sea salt uses the Gerber (1991) scheme, including the particle growth due to sulfate, ammonium and nitrate associated with the particles (Liu et al., 2005; Xu and Penner, 2012). Wet deposition scavenging parameterization is based on the wet scavenging scheme described by Mari et al. (2000) and Liu et al. (2001). Scavenging efficiencies for mineral dust and combustion-generated aerosols are calculated based on the amount of sulfate, ammonium and nitrate coated on the particles (Liu et al., 2005; Xu and Penner, 2012).

The dust alkalinity depends on dust mineralogy, dust particle size, meteorological conditions, and transport pathway of dust particles. Since volatile $\mathrm{CO}_{3}^{2-}$ in the alkaline carbonates (e.g., $\mathrm{CaCO}_{3}$ ) is replaced by less volatile $\mathrm{NO}_{3}^{-}$and nonvolatile $\mathrm{SO}_{4}^{2-}$, the $\mathrm{pH}$ buffering capacity of the original dust particles is compromised during long-range transport (Song et al., 2007). A comprehensive analysis of chemically aged individual Asian dust particles suggests that the reactivity of silicate particles to be mixed with nitrate, sulfate, and water is enhanced by the presence of internally mixed $\mathrm{CaCO}_{3}$ as a minor mineral (Song et al., 2013).

\subsection{Mineral dust composition}

Mineral dust is composed of variable amounts of clay minerals (e.g., illite, kaolinite, and smectite), carbonates (e.g., calcite), quartz, oxides (e.g., hematite), feldspars, and evaporite minerals (e.g., gypsum) (Claquin et al., 1999; Raiswell and Canfield, 2012). Hereinafter, hematite and goethite are referred to together using the common name HEM unless otherwise specified (Claquin et al. 1999; Nickovic et al., 2012). In atmospheric dust samples, clay minerals were often observed in the form of aggregates (Lafon et al., 2006). The size-resolved composition (volume percent) of mineral dust exhibited small compositional variations between different sizes (Kandler et al., 2007, 2009). An updated global database of soil minerals (Nickovic et al., 2012) was used to estimate the emissions of each mineral in dust aerosols by multiplying the total dust emission by the effective mineral content for four size bins of dust carried by the model. 
The database contains the mean mineral composition in clayand silt-sized soil particles as well as clay and silt fractions in soils within each $1 \mathrm{~km}$ grid cell (Nickovic et al., 2012). Clay- and silt-sized soil particles are particles with sizes less than $2 \mu \mathrm{m}$ and between 2 and $50 \mu \mathrm{m}$, respectively. The emitted effective mineral fractions were calculated as weighted means with respect to the clay and silt contents in soils using a $1 \mathrm{~km} \times 1 \mathrm{~km}$ grid. The data set was regridded to the $2.0^{\circ} \times 2.5^{\circ}$ grid resolution. Following Nickovic et al. (2013), the mean effective mineral fractions of clay and silt soil particles were uniformly assigned to all aerosol size bins for dust aerosols. The dust size distribution at emission follows the mass fractions of emitted soil particles in Kok (2011). We use the same effective mineral fractions for all sizes of aerosol particles, but these species (e.g., illite, smectite, calcite, hematite, and gypsum) are represented by specific tracers for each size bin. Since the dust $\mathrm{pH}$ is calculated for each bin separately, the dissolution rates are different among different size bins of mineral dust.

The calculated HEM content in the emitted dust $(0.6 \%$ for the percentage of Fe by weight) was significantly smaller than the average value of the $\mathrm{Fe}$ content $(3.5 \%)$ in upper crustal materials (Taylor and McLennan, 1985). The lower HEM content derived from the charts of the mineralogical composition of soil types may be associated with the extrapolation method of sparse data to large areas, its small content, and the difficulty in measuring the soil HEM content (Claquin et al., 1999). HEM was assumed to be coated on the particles, and its mineral content was extrapolated by the relationship between the HEM content and the redness in soils (Torrent et al., 1983; Claquin et al., 1999). The X-ray diffraction (XRD) was used to quantify the soil HEM content (Torrent et al., 1983). However, the conventional XRD is often not sensitive enough to detect iron oxides (Shi et al., 2012).

Electron-microscopy observations of dust particles show that iron is present as iron oxide grains in and on silicate particles as well as Fe-containing silicate (Formenti et al., 2011). Iron-containing aluminosilicate particles can occur as surface coatings ( $20 \%$ by volume) but most likely as heterogeneous inclusions (Kandler et al., 2009). The heterogeneous iron minerals associated with aluminosilicate particles might be formed by the oxidation of iron-containing aluminosilicate in the crust (Deboudt et al., 2012). The size of these Fe inclusions is typically about $100 \mathrm{~nm}$ (Deboudt et al., 2012), which can penetrate filters $(200$ or $450 \mathrm{~nm})$ when the mineral surface is dissolved. Cloud processing of dust after acid mobilization of iron might also form $\mathrm{Fe}$ nanoparticles of ferrihydrite (Shi et al., 2009). An increase in the fraction of total $\mathrm{Fe}$ that is in the form of ferrihydrite has been observed during the transport of Asian dust from western China to eastern China and Japan (Takahashi et al., 2011). Keeping in mind that the $\mathrm{Fe}$ content in clay minerals can be highly variable (Shi et al., 2012), the values for the Fe content are taken from the measurements by Journet et al. (2008): $11 \%$ for smectite $(2.55-23 \%), 4.0 \%$ for illite (3.4-4.7\%), $0.24 \%$ for kaolin- ite, and $0.34 \%$ for feldspar $(0.13-0.54 \%)$. As a result, the calculated mean value of the total Fe content in the emitted dust was $3.2 \%$ by weight. The averaged $\mathrm{Fe}$ content in dust precursors $(2.8 \pm 0.5 \%)$ and dust aerosols $(2.9 \pm 0.4 \%)$ is in good agreement with that of measurements (Lafon et al., 2004, 2006; Formenti et al., 2008; Lazaro et al., 2008; Shi et al., 2009, 2011a, b) (Table 1). Most iron is associated with aluminosilicates of smectite $(48 \%)$ and illite $(29 \%)$, rather than HEM (20\%). On a global average basis, $23 \%$ of iron (i.e., sum of the HEM and readily released $\mathrm{Fe}$ ) in total iron content is associated with iron oxides on mineral dust (i.e., free iron), which can be extracted by chemical reagents (Mehra and Jackson, 1960; Lafon et al., 2004). Note that free iron includes ferrihydrite, hematite and goethite on the mineral surface. The removal treatment of amorphous coatings and crystals of free iron oxides has almost no destructive effect on iron silicate clay minerals (Mehra and Jackson, 1960). Thus the remaining iron may include iron in the crystal lattice of silicates or iron oxides in clay that is not measured as free iron on clay (Karickhoff and Bailey, 1973; Deboudt et al., 2012). The larger fraction of free iron in total iron could be linked to the lower potential iron solubility (Shi et al., 2011b). The averaged ratio of free iron (i.e., sum of the HEM and readily released $\mathrm{Fe}$ on mineral dust) to total iron $(44 \pm 25 \%)$ for dust precursors and local aerosols is in good agreement with that of measurements $(44 \pm 19 \%)$ (Lafon et al., 2004, 2006; Shi et al., 2011b). Thus we associate the HEM in the inventory with a crystalline and micrometersized iron oxide, and use the term "micro-HEM" to refer to these particles hereinafter.

\subsection{Iron dissolution scheme}

Iron dissolution in dust aerosols due to atmospheric chemical processing is calculated from an online simulation of aerosolphase chemistry (Ito and Feng, 2010; Ito, 2012). The iron dissolution is treated explicitly as a kinetic process depending on the $\mathrm{pH}$, the mineral composition of iron-containing soils, the reactivity of iron species, the ambient temperature, and the degree of solution saturation. For dust aerosols, the rate of $\mathrm{Fe}$ dissolution $\left(R \mathrm{Fe}_{i}\right)$ in mineral $i$ (moles of filterable iron per gram of dust per second) can be empirically described by the following Eq. (Lasaga et al., 1994):

$R \mathrm{Fe}_{i}=N \mathrm{Fe}_{i} \times K_{i}(T) \times a\left(H^{+}\right)^{m i} \times f_{\mathrm{i}} \times A_{i} \times W_{i}$,

where $N \mathrm{Fe}_{i}$ is the stoichiometric number of moles of Fe per mole of mineral $i, K_{i}$ is the temperature ( $\left.T\right)$-dependent reaction coefficient (moles $\mathrm{m}^{-2} \mathrm{~s}^{-1}$ ) for mineral $i, a\left(\mathrm{H}^{+}\right)$is the $\mathrm{H}^{+}$activity, $m_{i}$ is the reaction order with respect to aqueousphase protons, $f_{\mathrm{i}}$ accounts for the effect of the solution saturation state on the dissolution rate (Cama et al., 1999), $A_{i}$ is the specific surface area of the mineral in units of $\mathrm{m}^{2} \mathrm{~g}^{-1}$, and $W_{i}$ is the weight fraction of mineral $i$ in the total dust in units of grams of mineral per gram of dust. The function $f_{i}$ 
Table 1. Iron oxide content in dust precursors and dust aerosols.

\begin{tabular}{|c|c|c|c|}
\hline Data & $\mathrm{FeA} / \mathrm{FeT}(\%)^{1}$ & $(\mathrm{FeA}+\mathrm{FeD}) / \mathrm{FeT}(\%)^{2}$ & $\operatorname{FeT}(\%)^{3}$ \\
\hline \multicolumn{4}{|l|}{ Dust precursors } \\
\hline Measurements ${ }^{4}$ & $1.7 \pm 2.1(N=10)^{6}$ & $44 \pm 19(N=14)^{6}$ & $3.7 \pm 2.2(N=14)^{6}$ \\
\hline Model & $2.4 \pm 1.1(N=10)^{6}$ & $44 \pm 25(N=14)^{6}$ & $2.8 \pm 0.5(N=14)^{6}$ \\
\hline \multicolumn{4}{|l|}{ Dust aerosols } \\
\hline Measurements ${ }^{5}$ & $1.7 \pm 0.8(N=3)^{6}$ & $44 \pm 12(N=9)^{6}$ & $3.8 \pm 1.0(N=6)^{6}$ \\
\hline Model & $2.8 \pm 0.3(N=3)^{6}$ & $25 \pm 6(N=9)^{6}$ & $2.9 \pm 0.4(N=6)^{6}$ \\
\hline \multicolumn{4}{|c|}{$\begin{array}{l}{ }^{1} \text { Ratio of the readily released } \mathrm{Fe}(\mathrm{FeA}) \text { to total iron }(\mathrm{FeT}) \text {. } \\
2 \text { Ratio of free iron (FeD) to total iron. Free iron includes ferrihydrite, hematite and goethite on the mineral surface. } \\
3 \text { Total Fe content in the dust. } \\
4 \text { Measurements for dust precursors and local aerosols (Lafon et al., 2004, 2006; Shi et al., 2011b). } \\
5 \text { Measurements for nonlocal aerosol, dry and wet deposition (Lafon et al., 2004, 2006; Formenti et al., 2008; Lazaro et } \\
\text { al., 2008; Shi et al., 2009, 2011a). } \\
6 \text { The parentheses represent the number of data points }(N) \text {. }\end{array}$} \\
\hline
\end{tabular}

is given by

$f_{\mathrm{i}}=1-Q_{i} / K \mathrm{eq}_{i}$

in which $Q_{i}$ is the dissolution activity quotient estimated at each time step and $K \mathrm{eq}_{i}$ is the equilibrium constant measured. The net dissolution rate under acidic conditions in Eq. (1) can be combined with Eq. (2) $\left(0 \leq f_{\mathrm{i}} \leq 1\right)$ and simplified for Fe species, $j$, by the following equation:

$R \mathrm{Fe}_{j}=k_{j} \times\left(1-\left(a_{\mathrm{Fe} 3+} \times a_{\mathrm{H}+}^{-n j}\right) / K \mathrm{eq}_{j}\right)$,

in which $k_{j}$ is the "far-from-equilibrium" (i.e., $f_{j}=1$ ) dissolution rate (moles $\mathrm{g}^{-1} \mathrm{~s}^{-1}$ ), $a_{\mathrm{Fe} 3+}$ is the concentration of $\mathrm{Fe}(\mathrm{III})$ in aerosol water $\left(\mathrm{mol} \mathrm{L}^{-1}\right)$, and $n_{j}$ is the stoichiometric ratio.

Results of laboratory experiments for the release of Fe with time showed that the rate of Fe released increases significantly with decreasing $\mathrm{pH}$ from 4 to 1 (Desboeufs et al., 1999; Mackie et al., 2005, 2006; Cwiertny et al., 2008; Shi et al., 2011a). The rate is independent of $\mathrm{pH}$ for extremely acidic solutions ( $\mathrm{pH}<1$ ) (Mackie et al., 2006). Thus we set $\mathrm{pH}=1$ for the calculation of Fe dissolution rates when $\mathrm{pH}<1$. Here we hypothesize that the observed $\mathrm{pH}$ dependence in the mineral aerosol dissolution data can be captured by different dissolution behaviors between different mineral properties. The faster reacting iron oxides (e.g., ferrihydrite and nanoparticulate) on aluminosilicate dissolve rapidly under highly acidic conditions $(\mathrm{pH}<2)$, while clay minerals slowly release iron nanoparticulate via the formation of a leached layer (Mackie et al., 2006; Journet et al., 2008; Shi et al., 2011a). The rest of iron is refractory iron. Thus three types of iron are distinguished in our model (Table 2):

1. Readily released Fe (e.g., ferrihydrite and nano-HEM aggregates on aluminosilicates): we assume two different Fe species of ferrihydrite and nano-HEM aggregates on illite and smectite, respectively, to emulate the dissolution curves of the "fast" and "intermediate" Fe pools in Shi et al. (2011a) (Fig. 1 and Table 3). We estimate the reaction coefficient of the ferrihydrite (nano-HEM) aggregates on illite (smectite) to reach $1.2 \%(0.3 \%)$ fractional iron solubility after $1 \mathrm{~h}$ at $\mathrm{pH}=2$ (Journet et al., 2008). The temperature dependence of $K_{i}(T)$ follows the Arrehenius Eq. (Lasaga et al., 1994). The activation energy for the dissolution of iron oxides is used $\left(76 \mathrm{~kJ} \mathrm{~mol}^{-1}\right)$ (Meskhidze et al., 2005). A first-order dependence on $\mathrm{pH}$ for protonpromoted dissolution of hematite nanoparticle aggregates (i.e., $m=1.0$ ) is used for iron oxides (i.e., ferrihydrite, nano-HEM and micro-HEM) (Lanzl et al., 2012). The equilibrium solubility of ferrihydrite and nano-hematite is obtained from the laboratory measurements (Bonneville et al., 2004). Since there is a lack of data for specific iron species in the mineralogical map, the fraction of total iron that is readily released iron at acidic $\mathrm{pH}$ is set to the potential Fe solubility associated with illite $(2.7 \%)$ and smectite $(5.0 \%)$ (Shi et al., 2011b), keeping in mind that these values can be highly variable (Shi et al., 2012). To represent water-soluble iron in soils, we prescribe the readily released iron attached on kaolinite (i.e., iron solubility at $4.3 \%$ ) and feldspar (i.e., iron solubility at $3.0 \%$ ) where $\mathrm{Fe}$ is in the form of impurities (Journet et al., 2008). The ratio of the sum of the readily released iron to total iron in dust precursors $(2.4 \pm 1.1 \%)$ is in good agreement with the measurements $(1.7 \pm 2.1 \%)$ (Shi et al., 2011b).

2. Slowly released Fe (e.g., heterogeneous inclusion of iron in aluminosilicates): although Fe can be present inside dust particles as a substitution element in the crystalline lattice of aluminosilicate, a high proportion ( $62 \%$ by number of particles) of iron-containing aluminosilicate particles are observed to be an internal 
Table 2. Global iron emission $\left(\mathrm{Fe} \mathrm{Tg} \mathrm{yr}^{-1}\right)$ estimated for different types of iron-containing mineral dust.

\begin{tabular}{lll}
\hline Type of Fe & Type of mineral & Fe emission \\
\hline Readily released Fe & Illite, smectite, kaolinite, feldspars & $3(3 \%)^{*}$ \\
Slowly released Fe & Illite, smectite & $60(77 \%)^{*}$ \\
Refractory Fe & HEM, kaolinite, feldspars & $17(22 \%)^{*}$ \\
\hline Total Fe & & 78 \\
\hline
\end{tabular}

* The parentheses represent the percentage of each type of Fe to total Fe.

mixture of aluminosilicate with iron oxide grains (Deboudt et al., 2012). We applied each dissolution rate of minerals, each effective mineral content, and each content of $\mathrm{Fe}$ in minerals to estimate the amount of iron released from each type of illite and smectite (Ito and Feng, 2010; Ito, 2012). The parameters used to calculate dissolution rates of illite $\left(\mathrm{K}_{0.6} \mathrm{Mg}_{0.25} \mathrm{Al}_{2.3} \mathrm{Si}_{3.5} \mathrm{O}_{10}(\mathrm{OH})_{2}\right)$ and smectite $\left(\mathrm{Na}_{0.6} \mathrm{Al}_{1.4} \mathrm{Mg}_{0.6} \mathrm{Si}_{4} \mathrm{O}_{10}(\mathrm{OH})_{2}\right)$ are listed in Table 1 of Ito (2012). Here, most iron in illite $(97 \%)$ and smectite $(95 \%)$ is assigned to slowly released iron, since the dissolution of iron associated with illite and smectite is generally slow in the model. Although precipitation of secondary phases could decrease clay mineral dissolution rates in some systems (e.g., extremely acidic ( $\mathrm{pH}<1)$, near-neutral, and alkaline solutions), this process is likely negligible under the acidic conditions (Köhler et al., 2005). We assume that iron can be released from clay minerals in the form of filterable iron ( $<200$ or $450 \mathrm{~nm}$ in solution), when the mineral surface is dissolved (Ito and Feng, 2010; Ito, 2012). The dissolution curves of the slowly released $\mathrm{Fe}$ are consistent with the laboratory experiments for the "slow" Fe pool during a typical aerosol lifetime (Shi et al., 2011a) (Fig. 1). Note that the lifetime of dust aerosols is between 2 and 7 days for most models (Huneeus et al., 2011).

3. Refractory $\mathrm{Fe}$ (e.g., crystalline and micrometer-sized iron oxides): a high proton $\left(\mathrm{H}^{+}\right)$concentration is required to destabilize the strong $\mathrm{Fe}-\mathrm{O}$ lattice bonds. Iron in the crystalline and micrometer-sized HEM can be slowly released over geological timescales, which are much longer than the times over which aerosols are exposed to highly acidic conditions. A previous study treated hematite dissolution as a three-stage kinetic process (Meskhidze et al., 2003), depending on the total amount of the hematite dissolved. We have applied this iron dissolution scheme to the major iron oxides in our previous version (Ito and Feng, 2010). Here, we set the rate constant to $1.8 \times 10^{-11} \times \exp$ [9200(1/298-1/T)] (moles $\mathrm{m}^{-2} \mathrm{~s}^{-1}$ ), which is the fastest stage of hematite dissolution among the three stages (Meskhidze et al., 2003). It takes about $1 \mathrm{~h}$ at $\mathrm{pH}=2$ to reach $0.01 \%$ fractional iron solubility, which is consistent with the operationally defined mass fraction of filterable iron from the laboratory measurements (Journet et al., 2008). The specific surface area of $9 \mathrm{~m}^{-2} \mathrm{~g}^{-1}$ for the commercial hematite sample (Journet et al., 2008) is consistent with that for the microhematite $\left(9.14 \mathrm{~m}^{-2} \mathrm{~g}^{-1}\right)$ made in the laboratory (Shi et al., 2011b). Thus we apply this scheme to the micro-HEM and regard it as refractory iron in total iron, because its dissolution rate is very slow under atmospherically relevant $\mathrm{pH}$ conditions. Kaolinites contain Fe oxides as impurities (Mermut and Cano, 2001). Most iron in kaolinite (96\%) and feldspar (97\%) is assigned to refractory iron.

In summary, our iron mobilization scheme successfully emulates the iron dissolution kinetics of mineral dust under the acidic conditions. The dissolution curves used in our standard simulations (red in Fig. 1) are in good agreement with the measured dissolution rates (black in Fig. 1) at $\mathrm{pH}=2$ and $\mathrm{pH}=3$, and initially for $\mathrm{pH}=1$. Although the model estimate deviates from the measurement after several hours at $\mathrm{pH}=1$, this $\mathrm{pH}$ condition is very rare for mineral dust in the atmosphere, because alkaline gases and carbonate minerals neutralize the acidic species in most cases. Iron at the initial condition is primarily insoluble iron. The amount of water-soluble $\mathrm{Fe}(<0.1 \%$ in total $\mathrm{Fe}$ by weight) is set by the readily released iron content of kaolinite and feldspar in dust at emissions. Iron is rapidly released from ferrihydrite and nano-HEM aggregates on illite and smectite under acidic $\mathrm{pH}$ until the system reaches equilibrium with respect to iron in the ferric form. As the acidity decreases from $\mathrm{pH}=2$ (red in Fig. $1 \mathrm{~b}$ and e) to $\mathrm{pH}=3$ (red in Fig. $1 \mathrm{c}$ and d), the Fe dissolution rate for iron oxides is reduced due to the saturation effect of $\mathrm{Fe}^{3+}$ in solution on the net dissolution rate in addition to slower far-from-equilibrium dissolution rate due to weaker protonation onto the surface of iron oxides (Eq. 3). After the initial rapid releases, the subsequent release of iron to solution occurs more slowly via dissolution of the clay mineral surface, which is consistent with that for Australian dust (Mackie et al., 2005, 2006). If the slowly released iron (77\% of the total Fe by weight on a global mean basis) is completely released to solution from the mineral dust, the release of iron effectively ceases, leaving only refractory iron 


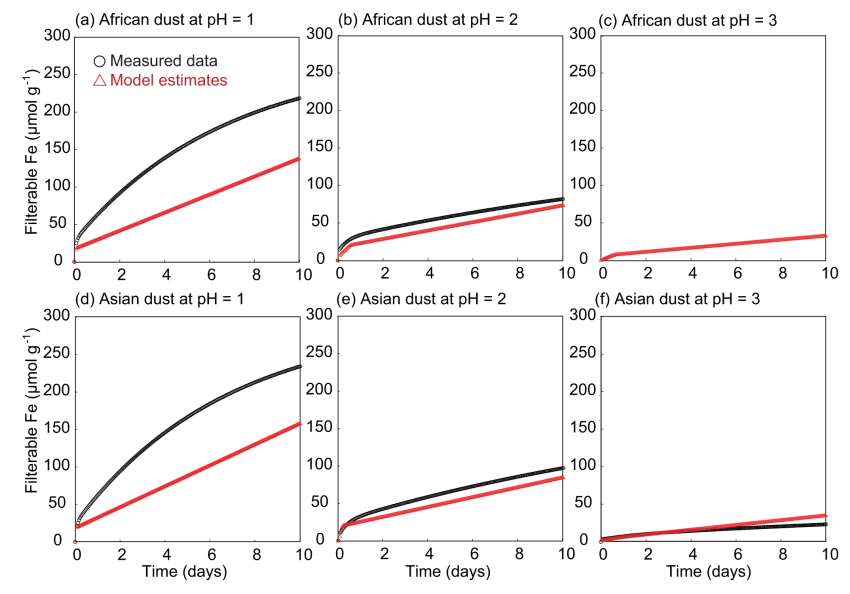

Fig. 1. Comparison of filterable Fe molar concentration per mass concentration of dust in solution $\left(\mu \mathrm{mol} \mathrm{g}{ }^{-1}\right)$ predicted from rate constants used in this study and the measured dissolution rates for African dust samples at (a) $\mathrm{pH}=1$, (b) $\mathrm{pH}=2$ and (c) $\mathrm{pH}=3$, and for Asian dust samples at (d) $\mathrm{pH}=1,(\mathbf{e}) \mathrm{pH}=2$ and (f) $\mathrm{pH}=3$. The red curves are calculated using Eq. (1) at each hour. The mineral composition in the dust source regions is calculated from the effective mineral map. The black curve is calculated using the fitting curve to the measured data (Shi et al., 2011a) at each hour. No measurement is available for African dust at $\mathrm{pH}=3$.

( $22 \%$ of the total Fe by weight) in and on dust particles. The slowly released iron is mainly composed of iron oxides in fine-grained materials internally mixed with aluminosilicate particles at emission (Deboudt et al., 2012).

In Fig. 2, we compare the modeled Fe dissolution rate from Australian dust under acidic condition $(\mathrm{pH}=2.15)$ with the measurement by Mackie et al. (2005). Overall, the Fe dissolution rate is in good agreement with that for Australian dust at diluted conditions $\left(<20 \mathrm{mg} \mathrm{L}^{-1}\right)$ where amount of Fe release was related only to the time of extraction (Mackie et al., 2005). The overestimate in iron solubility after $3 \mathrm{~h}$ may result from the lack of spatial variability of the mineral speciation of specific iron compounds in the iron map.

\subsection{Sensitivity experiments}

In the model each type of $\mathrm{Fe}$ is assigned separate tracers to analyze the effect of each component on iron and filterable iron deposition. After the standard simulation (Experiment 1), dust aerosol was separately treated from the sum of dust and combustion aerosols to isolate the effect of dust on estimates of iron and filterable iron deposition in Experiment 2 and Experiment 3 (Table 4). Further, the readily released $\mathrm{Fe}$ was separately treated from the sum of readily released, slowly released and refractory $\mathrm{Fe}$ to isolate the effect of the readily released $\mathrm{Fe}$ on estimates of iron solubility and filterable iron deposition in Experiment 3. This experiment used iron concentrations as in Experiment 2, but used filterable iron from readily released Fe only.

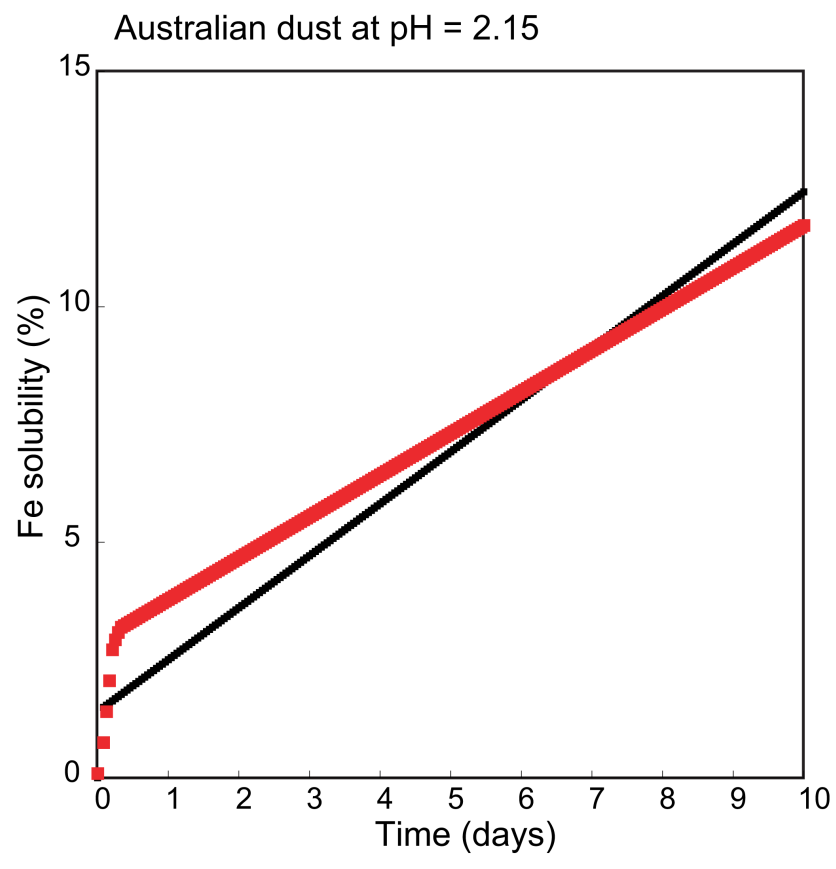

Fig. 2. Comparison of Fe solubility (\%) predicted from rate constants used in this study and the measured dissolution rates for Australian dust samples at $\mathrm{pH}=2.15$. The red curve is calculated using Eq. (1) at each hour. The mineral composition of the dust aerosol near Buronga, in the Mallee region of southwest New South Wales and northwest Victoria, Australia, in March is taken from the model estimates using the mineralogical map. The black curve for [dust] $=20.2 \mathrm{mg} \mathrm{L}^{-1}$ is calculated using the fitting curve to the measured data (Mackie et al., 2005) at each one hour. The initial Fe solubility of $1 \%$ probably represents Fe released during the $24 \mathrm{~h}$ equilibration in distilled-deionised water at $\mathrm{pH} \approx 4.5$ (Mackie et al., 2005).

To estimate the response of filterable iron deposition to improvement of air quality projected in the future, we used the anthropogenic emissions of the primary sources of combustion-generated aerosols and precursor gases $\left(\mathrm{SO}_{2}\right.$, $\mathrm{NO}_{2}$, and $\mathrm{NH}_{3}$ ) for 2100 together with each case of experiment for iron-containing mineral aerosols (Table 5). Specifically, we examine the sensitivity of dust deposition to scavenging efficiencies. Moreover, we examine the sensitivity of Fe solubility to dust acidification. The IPCC emission scenario RCP4.5 prescribes that pollution control levels increase over time in all countries as a function of income (Thomson et al., 2011). The ratios of the emissions from fossil fuel combustion in 2100 to those in 2000 were 0.19 for $\mathrm{SO}_{2}$ (Fig. S1a in the Supplement), 0.43 for particulate organic matter, and 0.48 for black carbon in RCP4.5. The ratios of total emissions in 2100 to those in 2000 were 0.64 for $\mathrm{NO}_{2}$ (Fig. S1b in the Supplement) and 1.1 for $\mathrm{NH}_{3}$ (Fig. S1c in the Supplement). The iron emissions from combustion sources are assumed to change linearly with the emissions of carbonaceous aerosols from RCP4.5 for Scenario 1 (Ito, 2013). We 
Table 3. Constants used to calculate iron dissolution rates for iron oxide aggregates on clay minerals.

\begin{tabular}{|c|c|c|c|c|c|c|c|c|c|}
\hline Mineral & Fe species & Chemical form & $N \mathrm{Fe}_{j}^{1}$ & Rate constant $K_{j}(T)^{2}$ & $m_{j}^{3}$ & $A_{j}^{4}$ & $K \mathrm{eq}^{5}$ & $n_{j}^{6}$ & $W \mathrm{Fe}_{j}^{7}$ \\
\hline Illite & Ferrid & $\mathrm{Fe}(\mathrm{OH})_{3}$ & 1 & $\begin{array}{l}1.17 \times 10^{-9} \exp \\
{\left[9.2 \times 10^{3}(1 / 298-1 / T)\right]}\end{array}$ & 1 & 205 & $4.17 \times 10^{1}$ & 2.75 & $1.09 \times 10^{-3}$ \\
\hline Smectite & Nano-HEM & $\mathrm{Fe}_{2} \mathrm{O}_{3}$ & 2 & $\begin{array}{l}8.78 \times 10^{-10} \exp \\
{\left[9.2 \times 10^{3}(1 / 298-1 / T)\right]}\end{array}$ & 1 & 125 & $3.31 \times 10^{0}$ & 2.85 & $5.36 \times 10^{-3}$ \\
\hline
\end{tabular}

${ }^{1} N \mathrm{Fe}_{j}$ is the stoichiometric number of moles of Fe per mole of Fe species $j$.

${ }^{2} K_{j}(T)$ is the temperature-dependent reaction coefficient (moles $\mathrm{m}^{-2} \mathrm{~s}^{-1}$ ) for each Fe species aggregates on each mineral.

${ }^{3} m_{j}$ is the reaction order with respect to aqueous-phase protons (Lanzl et al., 2012).

${ }^{4} A_{j}$ is the specific surface area of Fe species in units of $\mathrm{m}^{2} \mathrm{~g}^{-1}$ (Bonneville et al., 2004).

${ }^{5} \mathrm{Keq}$ is the equilibrium constant $\left(\mathrm{mol}^{2} \mathrm{~kg}^{-2}\right.$ ) (Bonneville et al., 2004).

${ }^{6} n_{j}$ is the stoichiometric ratio (Bonneville et al., 2004).

${ }^{7} \mathrm{WFe}_{j}$ is the weight fraction of the iron to mineral in units of $\mathrm{g}$ of iron ( $\mathrm{g}$ of mineral $)^{-1}$ (Journet et al., 2008; Shi et al., 2011b).

Table 4. Summary of iron emission sources used in sensitivity experiments.

\begin{tabular}{lll}
\hline & Dust $^{*}$ & Combustion \\
\hline Experiment 1 & All types & All sources \\
Experiment 2 & All types & Zero \\
Experiment 3 & Readily released Fe & Zero \\
\hline
\end{tabular}

* Iron-containing minerals include the readily released, slowly released, and refractory Fe, corresponding to those in Table 2.

also examined a sensitivity simulation in which only $\mathrm{SO}_{2}$ $\left(\mathrm{NO}_{2}\right)$ emissions from fossil fuel combustion decreases by 2100, but other emissions were kept the same as those for 2000 in Scenario 2 (Scenario 3). The differences between the present-day emissions and Scenario 2 (Scenario 3) can isolate the response of filterable iron deposition to $\mathrm{SO}_{2}\left(\mathrm{NO}_{2}\right)$ emission changes.

Future projections of dust deposition to the ocean are largely uncertain (Mahowald et al., 2009). In our approach, the effects of climate change, land-use change and $\mathrm{CO}_{2}$ increase on natural sources such as soil-derived dust and wild fires are not taken into account. Thus present-day estimates for mineral aerosols from arid and semiarid regions as well as combustion aerosols from biomass burning are used together with anthropogenic emission changes. Further research is needed to improve our understanding of the processes that alter dust and combustion-generated aerosol emissions due to climate, land-use, and $\mathrm{CO}_{2}$ changes for future projections. We also note that the changes in meteorological conditions from 2000 to 2100 that could change aerosol chemistry and deposition are not taken in account.

\subsection{Observational data set}

To assess model assumptions for iron dissolution, the calculated iron solubility is evaluated against a compilation of measurements from cruise ships over the oceans (Fig. 3). In Fig. 3, the western and eastern North Pacific Ocean is high-
Table 5. Summary of emission scenarios used in sensitivity experiments.

\begin{tabular}{|c|c|c|c|}
\hline & $\mathrm{SO}_{2}$ & $\mathrm{NO}_{2}$ & $\begin{array}{l}\text { Other anthropogenic } \\
\text { sources }\end{array}$ \\
\hline Scenario 1 & $2100^{*}$ & $2100^{*}$ & $2100^{*}$ \\
\hline Scenario 2 & $2100^{*}$ & Present day & Present day \\
\hline Scenario 3 & Present day & $2100^{*}$ & Present day \\
\hline
\end{tabular}

lighted for a comparison analysis (green and blue boxes, respectively). The daily average model results were calculated from hourly output at the surface to compare with ambient measurements along the cruise tracks (Chen and Siefert, 2004; Baker et al., 2006a, b; Buck et al., 2006, 2010; Sedwick et al., 2007; Aguilar-Islas et al., 2010; Hsu et al., 2010; Witt et al., 2010; Sholkovitz et al., 2012). A direct comparison of daily values between the global simulation and measurements from a variety of cruises is problematic. There are significant differences in the periods of aerosol collection, in the size segregation of the aerosol, and in the leaching solutions used to quantify an operationally defined mass concentration of filterable iron in the aerosol samples from different studies (Morton et al., 2013). The lack of consistency in experimental design makes it difficult to compare the results of different researchers, but the combined data show a consistent inverse relationship between the iron solubility and aerosol iron loading over the global scale that appears to dominate any effects due to methodological differences (Baker and Croot, 2010; Sholkovitz et al., 2012). If mineral aerosols are subject to a strong modulation due to the aging process that influences the overall iron solubility, one would expect higher solubility for more polluted conditions, but with some variability associated with the chemical aging times, the ambient levels of acidic and alkaline gases, the mineral source profiles (e.g., the reactivity of iron species and its content), and the meteorological conditions 


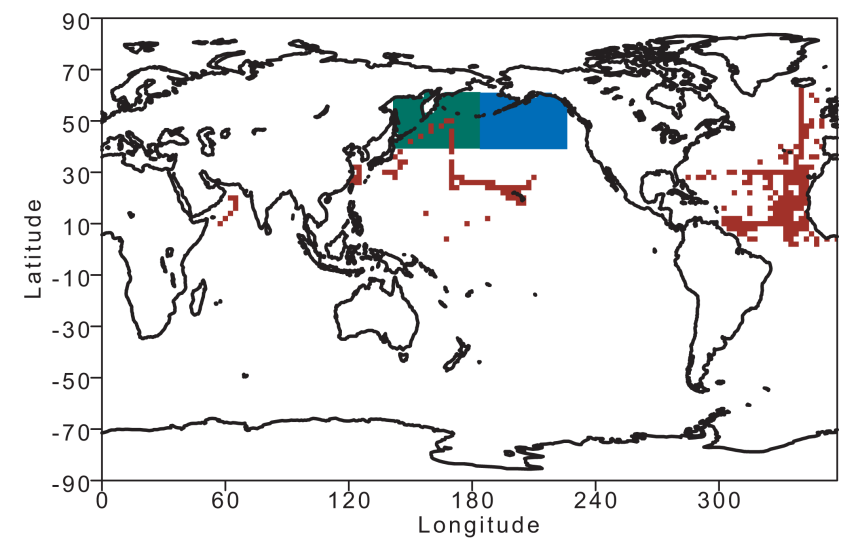

Fig. 3. The locations of ship cruises are represented using square symbols in red over the oceans from 2001 to 2008 (Chen and Siefert, 2004; Baker et al., 2006a, b; Buck et al., 2006, 2010; Sedwick et al., 2007; Aguilar-Islas et al., 2010; Hsu et al., 2010; Witt et al., 2010; Sholkovitz et al., 2012). The delimited areas in green and blue boxes are the western North Pacific $\left(40-60^{\circ} \mathrm{N}, 140-185^{\circ} \mathrm{E}\right)$ and the eastern North Pacific $\left(40-60^{\circ} \mathrm{N}, 185-230^{\circ} \mathrm{E}\right)$, respectively, and are used to calculate deposition estimates listed in Tables 6 and 7.

(e.g., temperature, humidity and pressure). Thus one way of assessing the sensitivity of iron solubility to environmental changes is to evaluate the variability in iron solubility under a variety of conditions. Here, we compare the model results to observations in the Northern Hemisphere only, because the amount of acidic trace gases may not be high enough to promote mineral-iron dissolution in the Southern Hemisphere (Johnson et al., 2010; Ito, 2012). Furthermore, other solubility-enhancing processes (e.g., multiple cycles of weathering, abrasion and uplift in the dust source region along its pathway to the ocean) and sources (e.g., savanna and forest fires) may be relatively more important for areas with low levels of atmospheric pollutants (Mackie et al., 2008; Ito, 2011, 2012).

\section{Results and discussion}

\subsection{Iron emission and deposition from dust}

The total emission rate of global mineral dust $\left(2480 \mathrm{Tg} \mathrm{yr}^{-1}\right.$ from Exp5) is higher than that of the median $\left(1123 \mathrm{Tg} \mathrm{yr}^{-1}\right)$ used in other simulations (Huneeus et al., 2011), partly due to different dust size distributions adopted in the emission mechanism (Ito et al., 2012). The geographical distribution of iron emission rates for readily released, slowly released and refractory $\mathrm{Fe}$ is compared in Fig. $4 \mathrm{a}, \mathrm{b}$ and c. North Africa, the Middle East/central Asia, east Asia and North America are the major dust source regions (> $100 \mathrm{ng} \mathrm{m}^{-2} \mathrm{~s}^{-1}$ ) in the Northern Hemisphere (Fig. 4d). The ratio of each type of Fe to total Fe generally shows little variability between different source areas, compared to the
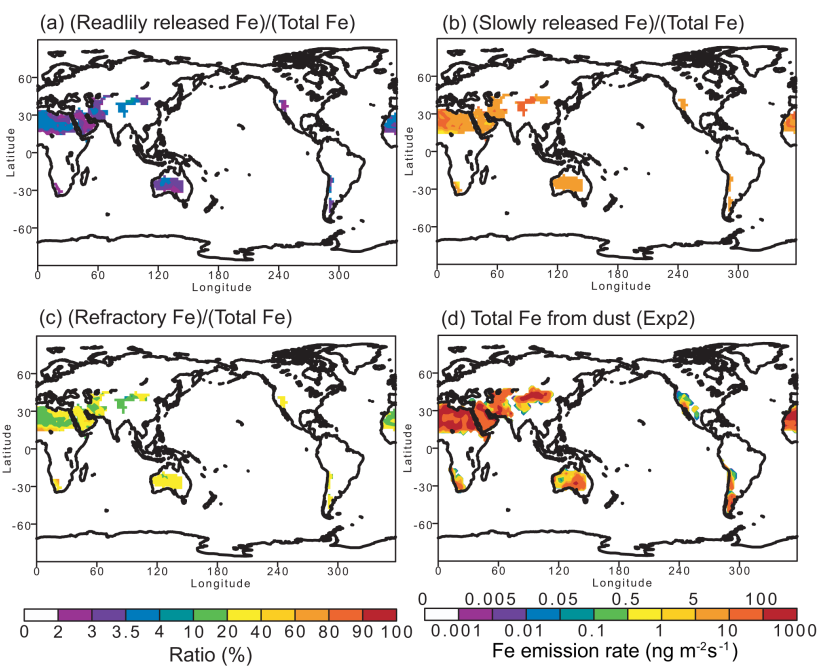

Fig. 4. The ratio (\%) of the iron emission rate of (a) readily released $\mathrm{Fe}$, (b) slowly released $\mathrm{Fe}$, and (c) refractory $\mathrm{Fe}$ to the total $\mathrm{Fe}$ from dust, and (d) the total iron emission rates $\left(\mathrm{ng} \mathrm{m}^{-2} \mathrm{~s}^{-1}\right)$ from dust (Experiment 2).

differences in the ratios between different Fe types. Slowly released $\mathrm{Fe}$ is the largest source of iron in iron-containing minerals (Experiment 2), providing $77 \%$ (by weight) of the total iron from dust emissions, followed by refractory (22\%) and readily released (3.2\%) (Table 2). Since we use the same mineralogical map and similar content of total iron in different minerals as in Nickovic et al. (2013), the ratio of refractory to total $\mathrm{Fe}$ indicates a similar plot of the ratio of the HEM content to total $\mathrm{Fe}$ as that in Nickovic et al. (2013). In particular, there is a belt in the Sahel with rather high values of the ratio (0.2-0.8) and in north Africa, parts of Algeria, Libya and Egypt (0.2-0.4). These values can be compared to the values in the remaining Saharan region (0.1-0.2).

The geographical distribution of iron deposition rates for the different Fe sources of readily released, slowly released and refractory Fe is compared in Fig. 5a, b and c. Asian dust is transported by the prevailing westerly wind over industrialized regions, where air pollutants (e.g., $\mathrm{SO}_{2}, \mathrm{NO}_{2}$, and $\mathrm{NH}_{3}$ ) are emitted, and then mainly deposited to the North Pacific $\left(0.1-5 \mathrm{ng} \mathrm{m}^{-2} \mathrm{~s}^{-1}\right)$, while African dust is mostly deposited in the North Atlantic (0.1-20 $\mathrm{ng} \mathrm{m}^{-2} \mathrm{~s}^{-1}$ ) (Fig. 5d). Deposition of iron from dust over the remote oceans such as the equatorial Pacific $\left(<0.1 \mathrm{ng} \mathrm{m}^{-2} \mathrm{~s}^{-1}\right)$ is smaller than that near the source regions. Our model results (Experiment 2) indicate that the majority of iron is supplied to open oceans from slowly released $\mathrm{Fe}(>60 \%)$ (Fig. $5 \mathrm{~b}$ ). The contributions of iron from readily released $\mathrm{Fe}$ to the total deposition are generally within $5 \%$ (Fig. 5a).

\subsection{Aerosol iron solubility}

The histogram of the aerosol iron solubility is plotted on a $\log _{10}$ scale for illustrative clarity in Fig. 6 for three model 

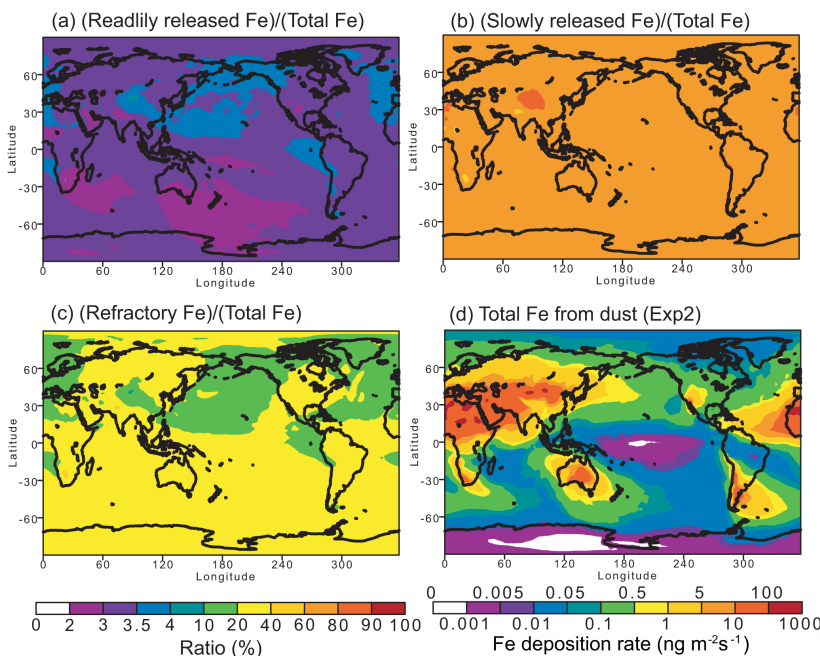

Fig. 5. The ratio (\%) of the iron deposition rate of (a) readily released $\mathrm{Fe}$, (b) slowly released $\mathrm{Fe}$, and (c) refractory $\mathrm{Fe}$ to the total $\mathrm{Fe}$ from dust, and (d) the total iron deposition rate $\left(\mathrm{ng} \mathrm{m}^{-2} \mathrm{~s}^{-1}\right)$ from dust (Experiment 2).

experiments (red), together with the observations (black). The number of data points, the mean bias in iron solubility between the model results and observations, the root mean square errors, and the ratio of the modeled and observed standard deviation are also listed in Fig. 6. The observations show a wider variability in iron solubility under different conditions (Fig. 6a). Experiment 1 considers all types of iron-containing minerals, including mineral dust and combustion aerosols (Fig. 6b). Experiment 2 (Fig. 6c) neglects the $\mathrm{Fe}$ sources from the combustion aerosols which were included in Experiment 1. The main mechanisms leading to higher iron solubility are the high iron solubility associated with combustion aerosols and the acid mobilization of iron associated with aluminosilicate particles. The former process is able to produce high iron solubility at low iron loading. Thus elevated iron solubility values (up to $78 \%$ ) are found when the combustion aerosols are included (Experiment 1), compared to the case that only includes dust (Experiment 2). The latter process is able to release water-insoluble iron in soils to solution in the form of ferrihydrite colloids, nanoparticles and aqueous species during the long-range transport. As a result, the model results from Experiment 1 and Experiment 2 are quite successful in simulating the enhanced iron solubility $(1-10 \%)$. The averaged iron solubility from Experiment $2(4 \pm 2 \%)$ is in good agreement with the observations $(6 \pm 8 \%)$. These results indicate that iron associated with clay minerals can play an important role in controlling the iron solubility $(0.1-10 \%)$. Moreover, the significant range in predicted iron solubility values $(0.1-10 \%)$ due to atmospheric chemical processing will have a large impact on the range of model-based estimates of filterable iron deposi-
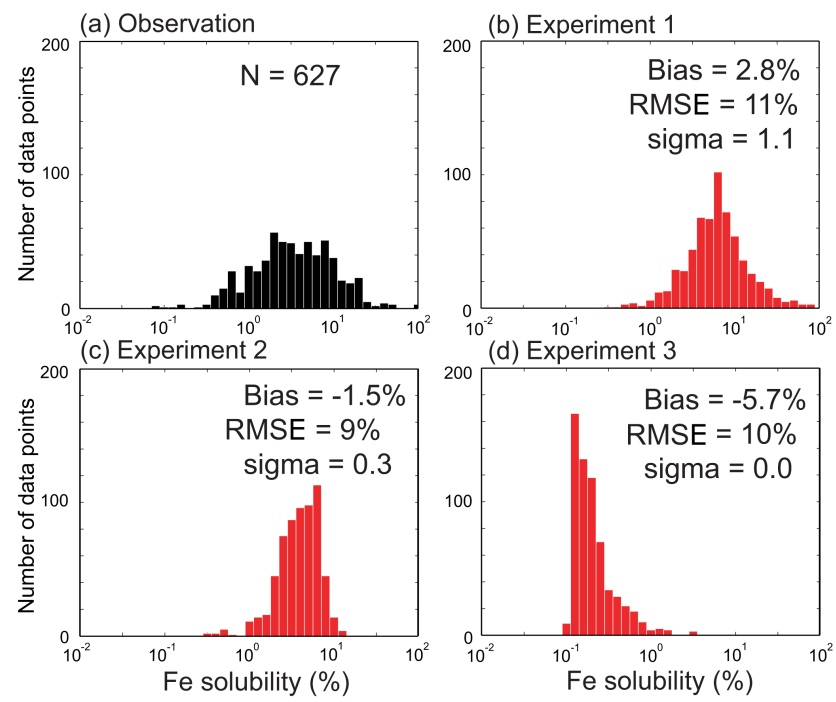

Fig. 6. Histogram (number of data points on vertical axis vs. iron solubility on horizontal axis) for (a) observations (black) from 2001 to 2008 (Chen and Siefert, 2004; Baker et al., 2006a, b; Buck et al., 2006, 2010; Sedwick et al., 2007; Aguilar-Islas et al., 2010; Hsu et al., 2010; Witt et al., 2010; Sholkovitz et al., 2012) and for model results (red) from (b) Experiment 1, (c) Experiment 2, and (d) Experiment 3 over the oceans in the Northern Hemisphere. The number of data points $(N)$, the mean bias between the model results and observations (Bias), the root mean square errors (RMSE) and the ratio of the modeled and observed standard deviation (sigma) are also shown. The daily average model results were calculated from hourly output at the surface to compare the model with ambient measurements along the cruise tracks. Experiment 1 includes all types of filterable Fe from combustion and dust sources. Experiment 2 (Experiment 3) includes all types of filterable Fe (readily released Fe only) from dust only.

tion and its response to changes in anthropogenic emissions of acidic trace gases.

Our sensitivity experiments in Experiment 2 (Fig. 6c) and Experiment 3 (Fig. 6d) demonstrate the effect of readily released iron sources on the prediction of iron solubility. Experiment 2 considers that readily released, slowly released and refractory $\mathrm{Fe}$ can exist in and on clay minerals ( $\mathrm{Ta}$ ble 3). Experiment 3 neglects the filterable Fe from slowly released iron (and the refractory iron) that is included in Experiment 2 . Our model results indicate that readily released iron on mineral dust (Experiment 3) did not contribute to an increase in Fe solubility $(0.3 \pm 0.3 \%)$, compared to the additional inclusion of iron in aluminosilicates (Experiment 2), which led to a better agreement with observations. These are mainly because $f_{\mathrm{i}}$ calculated for iron oxides (i.e., ferrihydrite, nano-HEM and micro-HEM) is close to zero in most cases except over the heavily polluted regions. These results suggest that the solution saturation effect in dust aerosol water can be a critical control on the observed enhancement in 
iron solubility from arid soils when considering the Fe dissolution of iron oxides.

Although our standard model (Experiment 1) captures the observations of iron solubility reasonably well, the contribution of readily released Fe could be conservative to some extent, because our dissolution scheme is primarily based on the laboratory experiments with no organic ligands. Paris et al. (2011) examined the effect of oxalate on iron dissolution from dust surrogate samples collected from the Sahara. Their results after $1 \mathrm{~h}$ at $\mathrm{pH}=4.7$ showed that the iron solubility increased from 0.0025 to $0.26 \%$ when oxalate concentration was increased from 0 to $8 \mu \mathrm{M}$. The value of $0.26 \%$ due to oxalate-promoted Fe dissolution during cloud processes is generally smaller than the model-predicted values in deposited mineral dust due to proton-promoted Fe dissolution in aerosol water (global average to the ocean is $2.8 \%$ in Fig. 7d), particularly in the Northern Hemisphere. Since filterable iron includes iron in aqueous phase, colloids, and nanoparticles in our model, whether iron in the forms of colloids and nanoparticles is transformed to iron-organics complexes (and thus dissolved iron) or not in cloud water will not affect the calculated filterable iron deposition, if the readily released $\mathrm{Fe}$ at emissions is a minor component in mineral dust. We note that the value of $0.26 \%$ at $\mathrm{pH}=4.7$ is larger than the water-soluble $\mathrm{Fe}$ content at emission in our model (global average at emission is $0.08 \%$ ), which is consistent with iron solubility in agricultural soils (less than $0.1 \%$ at an extraction $\mathrm{pH}$ of 4.65) (Sillanpää, 1982). Thus the effect of organic acid is potentially important in pristine regions where inorganic acids concentrations are too low to promote Fe dissolution from mineral dust particles but the organic acids concentrations are high enough. Acknowledging that our model prediction is not a complete picture, the chemical form of iron in aerosol and cloud water for investigations of photochemical reduction and ligand-promoted iron dissolution will be explored by using a multiphase process model that predicts aqueous oxalate formation in a future version of our model. Although the exchange of Fe between different chemical forms in solution is not characterized specifically, our simulations provide the first estimate of filterable iron deposition in association with future changes in air quality.

\subsection{Filterable iron deposition from dust}

The geographical distribution of filterable iron deposition rates for the different sources of readily released and slowly released iron are compared in Fig. 7a and b. Refractory iron is not shown in Fig. 7, because the filterable iron deposition from refractory iron is negligible. Our model results (Experiment 2) indicate that Asian dust supplies less filterable iron into the North Pacific (0.001-0.05 $\left.\mathrm{ng} \mathrm{m}^{-2} \mathrm{~s}^{-1}\right)$ than does African dust into the North Atlantic (0.01-1 $\mathrm{ng} \mathrm{m}^{-2} \mathrm{~s}^{-1}$ ) (Fig. 7c). The spatial pattern of the ratio of the filterable iron deposition of each type of $\mathrm{Fe}$ to the total deposition into the oceans (Fig. 7a and b) mainly reflects the differences in their

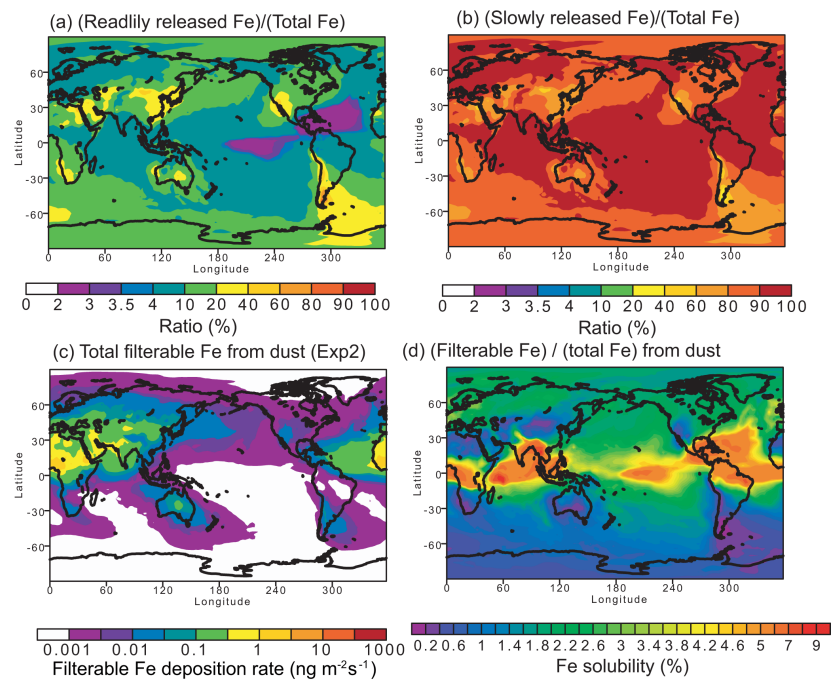

Fig. 7. The ratio $(\%)$ of the filterable iron deposition rate of (a) readily released $\mathrm{Fe}$ and (b) slowly released $\mathrm{Fe}$ to the sum of readily and slowly released $\mathrm{Fe}$, (c) total filterable iron deposition rate $\left(\mathrm{ng} \mathrm{m}^{-2} \mathrm{~s}^{-1}\right)$ from dust (Experiment 2$)$, and (d) ratio (\%) of the filterable iron deposition to total iron deposition from dust (Experiment 2).

Fe deposition rates (Fig. 5). However, the filterable iron deposition results in weaker regional gradients, with high fluxes in the western North Pacific (0.01-0.05 $\left.\mathrm{ng} \mathrm{m}^{-2} \mathrm{~s}^{-1}\right)$ and low to the eastern North Pacific (0.001-0.01 $\left.\mathrm{ng} \mathrm{m}^{-2} \mathrm{~s}^{-1}\right)$, which reflect more filterable iron released from the dust as it travels from the east Asian desert regions.

To quantify the importance of the atmospheric chemical transformation of iron in mineral aerosols, we show the model-predicted (filterable Fe/total Fe) (\%) deposited mineral dust (Fig. 7d). In general, Fe solubility values remain low near the dust source regions but increase downwind as acidic trace gases enhance iron mobilization. The high Fe solubility values are predicted over the regions characterized by low concentrations of dust and high amounts of anthropogenic pollution in the Northern Hemisphere. On the other hand, Fe solubility values remain low over regions in the Southern Hemisphere. Our iron solubility for mineral dust is generally higher than the dissolved Fe fraction for hematite in dust aerosols predicted by Johnson and Meskhidze (2013), which partly reflects the different definitions of potentially bioavailable iron between filterable iron and dissolved iron. Our modeled Fe solubility values are highly dependent on the predicted $\mathrm{pH}$ of mineral aerosols (Fig. S2 in the Supplement). In our model, the aerosol $\mathrm{pH}$ in the coarse particles (radius: $1.25-10 \mu \mathrm{m}$ ) is higher than that in the fine particles (radius: $<1.25 \mu \mathrm{m}$ ).

The model results shown in Fig. 7 suggest that slowly released Fe minerals in smectite and illite provide the dominant source of the deposition of filterable iron to the oceans ( $>80 \%$ ), while readily released Fe contributes $4-20 \%$ of the 
filterable iron deposition to the Pacific downwind from Asian dust source regions. The monthly averaged ratio of the sum of the readily released iron and filterable iron from slowly released iron to total iron $(2.8 \pm 0.3 \%)$ in dust aerosols from Experiment 2 is larger than the measurements for the dust storm events $(1.7 \pm 0.8 \%)$ (Shi et al., 2009, 2011a) (Table 1). On the other hand, the monthly averaged ratio of free iron (i.e., sum of the readily released iron, macro-HEM, and filterable iron from slowly released iron) to total iron $(25 \pm 6 \%)$ from Experiment 2 is significantly smaller than that of measurements for nonlocal aerosol, dry and wet deposition (44 $\pm 12 \%$ ) (Lafon et al., 2004, 2006; Formenti et al., 2008; Lazaro et al., 2008; Shi et al., 2009, 2011a). However, the measurements of the dust storm particles from the desert areas of northern China and parts of Mongolia indicated similar magnitudes of different ratios (i.e., $24 \%$ for Beijing and $52 \%$ for Zhenbaitai) (Lafon et al., 2004; Shi et al., 2011a). Various factors can contribute to the differences and similarities for nonlocal aerosols. The main potential cause of difference in the ratio of free to total iron is due to the lack of specific $\mathrm{Fe}$ oxides, especially goethite, in the mineralogical map (Lafon et al., 2004, 2006). More observations are needed to improve our understanding of the emission and transformation processes of iron-containing mineral aerosols.

\subsection{Sensitivity of deposition to emissions of air pollutants}

We compared the average deposition rate of iron and filterable iron from dust and combustion aerosols in Scenario 1 (Fig. 8a and 8b) to that for the present day (Experiment 1). The spatial pattern of iron and filterable iron deposition rate from the sum of dust and combustion sources to the oceans in Scenario 1 (Fig. 8a and b) is similar to the pattern from dust only (Fig. 5d and Fig. 7c). However, the filterable iron deposition rate from dust and combustion sources (Experiment 1) into the the high-latitude North Atlantic and North Pacific (0.01-0.05 $\left.\mathrm{ng} \mathrm{m}^{-2} \mathrm{~s}^{-1}\right)$ is larger than that from dust only (Experiment 2), which reflects higher iron solubility $(80 \%)$ of the oil combustion aerosols (Ito, 2013). In order to quantify the effects of the dust sources on the total input of filterable Fe into the ocean, the deposition from dust is compared to that from combustion aerosols (Table 6). The model results indicate that the majority of iron is transported from arid and semiarid regions to the subarctic North Pacific $(97-98 \%)$, while a significant fraction of filterable iron is supplied from combustion sources (29-54\%). Consequently, the improvement of air quality projected in the future will lead to a decrease of the total filterable iron deposition to the western North Pacific from 5.2 to $4.7 \mathrm{Gg} \mathrm{yr}^{-1}(-10 \%)$ due to less acidification in Asian dust (Fig. S2 in the Supplement). At the same time, continuing growth in global shipping and no regulations regarding particle emissions over the open ocean led to the increase of the total filterable iron de-

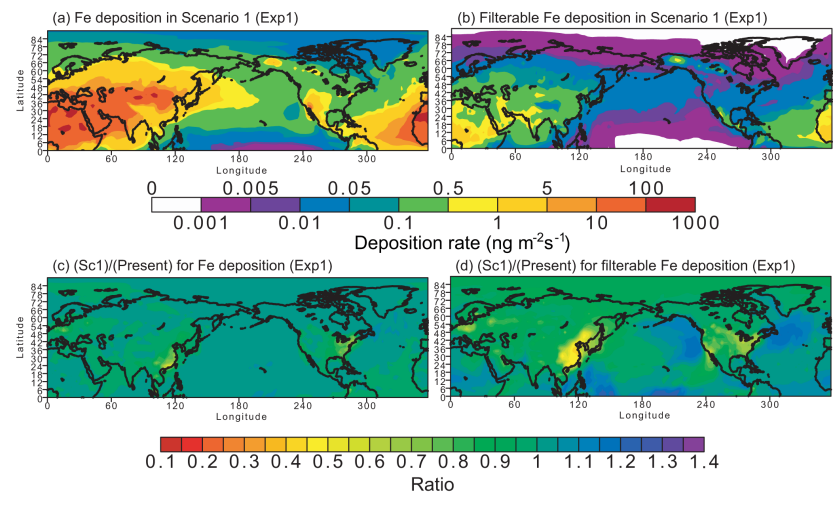

Fig. 8. Annually averaged deposition rate $\left(\mathrm{ng} \mathrm{m}^{-2} \mathrm{~s}^{-1}\right)$ of (a) iron (Fe) and (b) filterable iron from the sum of dust and combustion aerosols in Scenario 1 (Experiment 1). Responses of (c) iron and (d) filterable iron depositions to changes in all anthropogenic emissions (i.e., combustion-generated iron, carbonaceous aerosols, $\mathrm{SO}_{2}, \mathrm{NO}_{2}$ and $\mathrm{NH}_{3}$ ) from 2000 to 2100 (Scenario 1). The results of the iron and filterable iron deposition to the western North Pacific Ocean $\left(40-60^{\circ} \mathrm{N}, 140-185^{\circ} \mathrm{E}\right)$ and the eastern North Pacific $\left(40-60^{\circ} \mathrm{N}\right.$, $\left.185-230^{\circ} \mathrm{E}\right)$ are shown in Table 6.

position to the eastern North Pacific from 2.7 to $3.0 \mathrm{Gg} \mathrm{yr}^{-1}$ (11\%) (Ito, 2013).

The deposition rates of iron and filterable iron from dust are separated from combustion aerosols (Experiment 2 and Experiment 3). We compared the ratio of the average deposition rate of iron and filterable iron from dust in Scenario 1 to that for the present day (Experiment 2 and Experiment 3) (Fig. 9a, b and c). Future improvements in air quality decrease the scavenging of dust by reducing the soluble materials on the surface of dust over polluted regions, and thus slightly increase the deposition of iron to the North Pacific Ocean (1.0-1.1). The deposition flux of filterable iron decreases substantially, especially for readily released $\mathrm{Fe}$ (0.3-0.7 over the North Pacific), because the acid mobilization of iron is weakened by the reduction of pollutant emissions. We calculated the iron and filterable iron deposition from dust over the subarctic North Pacific $\left(40-60^{\circ} \mathrm{N}, 140\right.$ $230^{\circ} \mathrm{E}$ ) (Table 7). Improvements in air quality (Scenario 1) marginally increase the deposition of iron to the subarctic North Pacific from 261 to $265 \mathrm{Gg} \mathrm{yr}^{-1}$, but result in substantially larger reduction in the deposition of filterable iron to the subarctic North Pacific for Experiment 2 from 5.2 to $4.4 \mathrm{Gg} \mathrm{yr}^{-1}(-15 \%)$ and that for Experiment 3 from 0.68 to $0.35 \mathrm{Gg} \mathrm{yr}^{-1}(-48 \%)$. The stronger response for readily released Fe mainly reflects the effect of the solution saturation state on the dissolution rate (i.e., decrease of $f_{\mathrm{i}}$ in Eq. (1) due to decrease of $a_{\mathrm{H}+}$ in Eq. 3). Consequently, the contribution of readily released Fe to total filterable iron deposition decreased from 13 to $8 \%$.

Further, we investigated the response of filterable iron deposition from dust to changes in only $\mathrm{SO}_{2}\left(\mathrm{NO}_{2}\right)$ emissions from 2000 to 2100 (Fig. 9d-g). In our model, sulfate is 
Table 6. Depositions of iron and filterable iron $\left(\mathrm{Gg} \mathrm{yr}^{-1}\right)$ from mineral dust and combustion sources to the western and eastern North Pacific (Experiment 1$)^{1}$.

\begin{tabular}{|c|c|c|c|c|}
\hline & \multicolumn{2}{|c|}{ Present day } & \multicolumn{2}{|c|}{ Future (Scenario 1) } \\
\hline & Dust & Combustion & Dust & Combustion \\
\hline \multicolumn{5}{|c|}{ Western North Pacific } \\
\hline Iron & $187(97 \%)^{2}$ & $5.7(3.0 \%)^{2}$ & $191(98 \%)^{2}$ & $4.5(2.3 \%)^{2}$ \\
\hline Filterable iron & $3.7(71 \%)^{2}$ & $1.5(29 \%)^{2}$ & $3.1(65 \%)^{2}$ & $1.7(35 \%)^{2}$ \\
\hline \multicolumn{5}{|c|}{ eastern North Pacific } \\
\hline Iron & $74(97 \%)^{2}$ & $2.2(2.9 \%)^{2}$ & $76(97 \%)^{2}$ & $2.5(3.1 \%)^{2}$ \\
\hline Filterable iron & $1.5(55 \%)^{2}$ & $1.2(45 \%)^{2}$ & $1.4(46 \%)^{2}$ & $1.6(54 \%)^{2}$ \\
\hline $\begin{array}{l}1 \text { The amounts of iror } \\
\text { calculated from the re } \\
\text { anthropogenic emissi } \\
\mathrm{NH}_{3} \text { ) in } 2100 \text {. }\end{array}$ & $\begin{array}{l}\mathrm{d} \text { filterable iron } \\
\mathrm{s} \text { of deposition } \mathrm{r} \\
\text { (i.e., combustion }\end{array}$ & $\begin{array}{l}\text { ssition to the we } \\
\text { shown in Fig. } \\
\text { nerated iron, ca }\end{array}$ & $\begin{array}{l}n \text { and eastern } N \\
\text { e future scenar } \\
\text { aceous aerosol }\end{array}$ & $\begin{array}{l}\text { h Pacific are } \\
\text { Scenario } 1 \text {, uses al } \\
\mathrm{O}_{2}, \mathrm{NO}_{2} \text { and }\end{array}$ \\
\hline
\end{tabular}

Table 7. Deposition of iron and filterable iron $\left(\mathrm{Gg} \mathrm{yr}^{-1}\right)$ from dust to the subarctic North Pacific*.

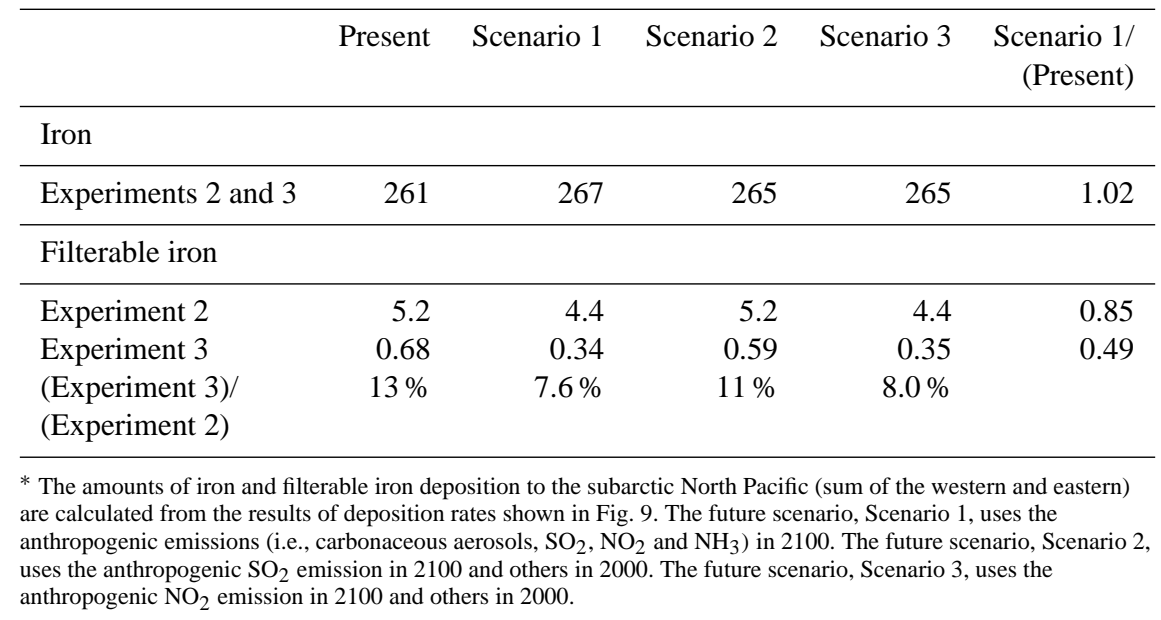

largely in the accumulation mode (radius $<1 \mu \mathrm{m}$ ), while nitrate is mainly associated with dust in the coarse mode. As a result, the aerosol $\mathrm{pH}$ in the fine mode (radius $<0.63 \mu \mathrm{m}$ ) is generally lower (more acidic) than the coarse mode (radius $>0.63 \mu \mathrm{m}$ ) (Fig. S2 in the Supplement). Since the majority of dust deposition occurs in the coarse mode, the response of filterable iron deposition to the reduction in $\mathrm{SO}_{2}$ emissions (and no change in other emissions) is smaller than that to the reduction in $\mathrm{NO}_{2}$ emissions (and no change in other emissions). The reduction in $\mathrm{NO}_{2}$ emissions leads to the slight decrease in the filterable iron deposition from dust to the western North Pacific (0.8-0.9), but to a substantial decrease from the readily released $\mathrm{Fe}$ in the filterable iron deposition (0.3-0.7). In the subarctic North Pacific (Table 7), the changes in the filterable iron deposition can be mainly associated with the $\mathrm{NO}_{2}$ emission changes alone (Scenario 3), because most of the dust mass resides in the coarse mode, even though the solubility of iron in the coarse mode is lower than that in the accumulation mode.

\section{Conclusions}

The knowledge of the specific mineral properties (e.g., chemical composition, specific Fe content, and its dissolution rate) is a key factor in reducing uncertainties in the prediction of the iron solubility. In this study, the scavenging efficiency of dust particles depends on the surface coating of these aerosols by sulfate, nitrate and ammonium. In the aging process, filterable iron in dust was released in solution, based on the reactivity of different types of iron associated with mineral properties as a function of aerosol acidity. The iron dissolution curves estimated in our simulations were in good agreement with the laboratory measurements. We conducted comparisons of the iron solubility from the model 


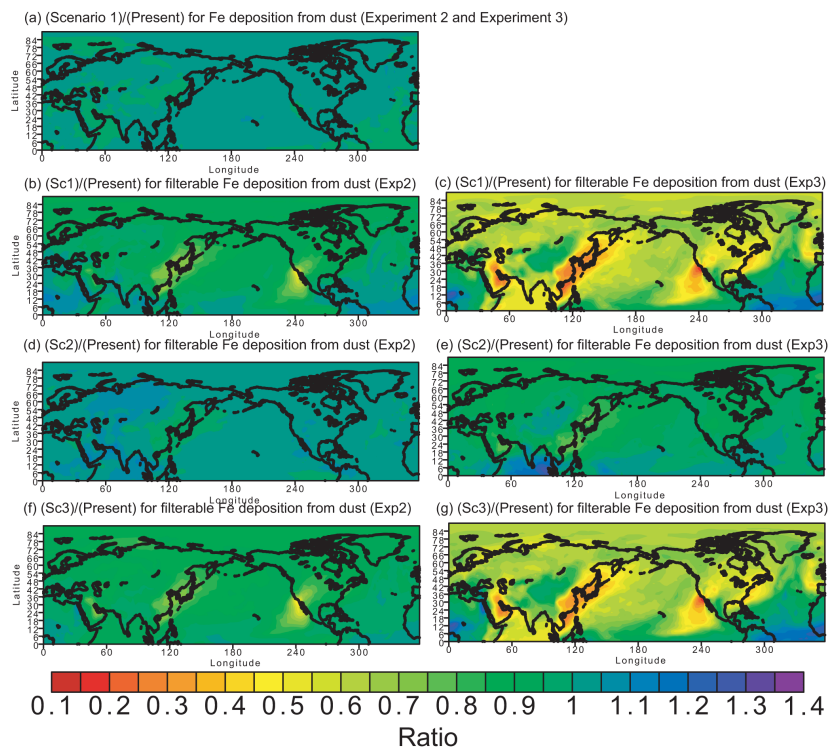

Fig. 9. The ratios of (Scenario 1)/(Present) for iron (Fe) deposition from dust (a) Experiment 2 and Experiment 3 represent the changes due to changes in the anthropogenic emissions (i.e., carbonaceous aerosols, $\mathrm{SO}_{2}, \mathrm{NO}_{2}$ and $\mathrm{NH}_{3}$ ) from 2000 to 2100. The ratios of (Scenario 1)/ (Present) for filterable iron deposition from dust (b) Experiment 2 and (c) Experiment 3 represent the changes due to changes in the anthropogenic emissions (i.e., carbonaceous aerosols, $\mathrm{SO}_{2}, \mathrm{NO}_{2}$ and $\mathrm{NH}_{3}$ ) from 2000 to 2100. The ratios (\%) of (Scenario 2) / (Present) for filterable iron deposition from dust (d) Experiment 2 and (e) Experiment 3 represent the changes due to the change in only $\mathrm{SO}_{2}$ emission from 2000 to 2100 . The ratios of (Scenario 3) / (Present) for filterable iron deposition from dust (f) Experiment 2 and (g) Experiment 3 represent the changes due to the change in only $\mathrm{NO}_{2}$ emission from 2000 to 2100 . The results of the iron and filterable iron depositions to the subarctic North Pacific Ocean $\left(40-60^{\circ} \mathrm{N}, 140-230^{\circ} \mathrm{E}\right)$ are shown in Table 7.

with cruise-based observations to evaluate whether the use of this parameterization in a model could provide reasonable predictive capability for assessments of the potential impact of future anthropogenic activity on the bioavailable iron cycle.

Our model demonstrated that the improved treatment of Fe in mineral dust and its dissolution scheme resulted in reasonable predictive capability for iron solubility over the oceans in the Northern Hemisphere. It should be noted that the direct comparison of the daily averages of iron solubility to validate the model is inherently difficult, especially at low iron solubility during dust events. The model results suggest that the iron as heterogeneous inclusions in aluminosilicate dust could be released in the form of ferrihydrite colloids, nanoparticles and aqueous species during the long-range transport and thus potentially provide an important bioavailable source of iron to the oceans in the Northern Hemisphere. Although readily released $\mathrm{Fe}$ produce filterable $\mathrm{Fe}$ more quickly under highly acidic conditions $(\mathrm{pH}<2)$, slowly re- leased $\mathrm{Fe}$ appears to be important at higher $\mathrm{pH}$ values during long-range transport. This difference is likely linked to the dominant mechanism of iron dissolution in mineral aerosols. Two key underlying problems have nevertheless been identified. The major problem is a lack of spatial variability in content of specific Fe species in the Fe map. Practically, we assume that the major iron oxides were the Fe nanograins (typically $100 \mathrm{~nm}$ ) in aluminosilicate particles while iron oxides on aluminosilicate particles were mostly in the form of microaggregates of nano-HEM or micro-HEM. The chemical formulation of each type of iron, its formation process and its dissolution rate are active research topics. The mineralogical map needs to be combined with chemical composition of clay minerals and specific type of Fe species in the future. Further research is needed to understand the spatial variability of the mineral speciation of specific iron compounds for the partitioning of each mineral into size-segregated particles in the atmosphere. The lack of organic ligands in our model is also an important source of uncertainty. The amount of iron associated with clays can be highly variable, and its dissolution/precipitation may strongly depend on the organic ligands in water. Further modeling and laboratory experimental studies are needed for the Fe dissolution kinetics of ironcontaining minerals and the $\mathrm{pH}$ effect on the $\mathrm{Fe}$ solubility under atmospherically relevant conditions of organic acids concentrations and $\mathrm{pH}$.

It has been suggested that increases in iron deposition from desert dust since 1870 are likely to have fertilized ocean biota, enhanced nitrogen fixation, and resulted in a negative radiative forcing of $-0.07 \pm 0.07 \mathrm{~W} \mathrm{~m}^{-2}$ (Mahowald, 2011). Iron-fertilized diatom blooms may sequester carbon for timescales of centuries in ocean bottom water and for longer in sediments (Smetacek et al., 2012). Thus, understanding how ocean uptake of carbon dioxide will be modified in the future is an important issue for projecting climate change. We applied the changes in anthropogenic emissions of combustion-generated aerosols and precursor gases from 2000 to 2100 (RCP4.5) in our global chemical transport model in order to examine the chemical modification of iron-containing aerosols to environmental changes in air quality that influence both the release of iron associated with mineral dust and the emissions of combustion aerosols. Our model response to the changes in anthropogenic emissions showed the negative sign of the change in filterable iron deposition to the western North Pacific $(-10 \%)$ if environmental policies are successful. On the other hand, due to the increase in global shipping emissions, our model response was the positive sign $(11 \%)$ in the eastern North Pacific. Consequently, the spatial pattern of filterable iron deposition to the subarctic Pacific showed remarkably little gradient from Asian dust source regions, in contrast to that calculated with a globally uniform solubility approximation. The effects of environmental changes on the filterable iron deposition from both the dust and combustion aerosols need to be considered 
comprehensibly in order to correctly predict the change in the bioavailable iron deposition in the future.

\section{Supplementary material related to this article is available online at http://www.atmos-chem-phys.net/14/ 3441/2014/acp-14-3441-2014-supplement.pdf.}

Acknowledgements. Support for this research was provided to A. Ito by the Program for Risk Information on Climate Change (MEXT). All of the numerical simulations were performed using the SGI ICE $X$ at the JAMSTEC. The authors are grateful to J. E. Penner at the University of Michigan for helpful comments on an earlier draft.

Edited by: A. Laskin

\section{References}

Aguilar-Islas, A. M., Wu, J., Rember, R., Johansen, A. M., and Shank, L. M.: Dissolution of aerosol-derived iron in seawater: Leach solution chemistry, aerosol type, and colloidal iron fraction, Mar. Chem., 120, 25-33, 2010.

Baker, A. R. and Croot, P. L.: Atmospheric and marine controls on aerosol iron solubility in seawater, Mar. Chem., 120, 4-13, 2010.

Baker, A. R. and Jickells, T. D.: Mineral particle size as a control on aerosol iron solubility, Geophys. Res. Lett., 33, L17608, doi:10.1029/2006GL026557, 2006.

Baker, A. R., French, M., and Linge, K. L.: Trends in aerosol nutrient solubility along a west-east transect of the Saharan dust plume, Geophys. Res. Lett., 33, L07805, doi:10.1029/2005GL024764, 2006a.

Baker, A. R., Jickells, T. D., Witt, M. and Linge, K. L.: Trends in the solubility of iron, aluminum, manganese and phosphorus in aerosol collected over the Atlantic Ocean, Mar. Chem., 98, 43$58,2006 \mathrm{~b}$

Bonneville, S., Van Cappellen, P., and Behrends, T.: Microbial reduction of iron(III) oxyhydroxides: effects of mineral solubility and availability, Chem. Geol., 212, 255-268, 2004.

Bowie, A. R., Lannuzel, D., Remenyi, T. A., Wagener, T., Lam, P. J., Boyd, P. W., Guieu, C., Townsend, A. T., and Trull, T. W.: Biogeochemical iron budgets of the Southern Ocean south of Australia: Decoupling of iron and nutrient cycles in the subantarctic zone by the summertime supply, Global Biogeochem. Cy., 23, GB4034, 14 pp., doi:10.1029/2009GB003500, 2009.

Buck, C. S., Landing, W. M., Resing, J. A., and Lebon, G. T.: Aerosol iron and aluminum solubility in the northwest Pacific Ocean: Results from the 2002 IOC cruise, Geochem. Geophy. Geosy., 7, Q04M07, doi:10.1029/2005GC000977, 2006.

Buck, C. S., Landing, W. M., and Resing, J. A.: Particle size and aerosol iron solubility: A high-resolution analysis of Atlantic aerosols, Mar. Chem., 120, 14-24, doi:10.1016/j.marchem.2008.11.002, 2010.

Cama, J., Ayora, C., and Lasaga, A. C.: The deviation-fromequilibrium effect on dissolution rate and on apparent variations in activation energy, Geochim. Cosmochim. Ac., 63, 2481-2486, 1999.
Chen, H., Laskin, A., Baltrusaitis, J., Gorski, C. A., Scherer, M. M., and Grassian, V. H.: Coal fly ash as a source of iron in atmospheric dust, Environ. Sci. Technol., 46, 2112-2120, 2012.

Chen, Y. and Siefert, R. L.: Seasonal and spatial distributions and dry deposition fluxes of atmospheric total and labile iron over the tropical and subtropical North Atlantic Ocean, J. Geophys. Res., 109, D09305, doi:10.1029/2003JD003958, 2004.

Chuang, P. Y., Duvall, R. M., Shafer, M. M., and Schauer, J. J.: The origin of water soluble particulate iron in the Asian atmospheric outflow, Geophys. Res. Lett., 32, L07813, doi:10.1029/2004GL021946, 2005.

Claquin, T., Schulz, M., and Balkanski, Y. J.: Modeling the mineralogy of atmospheric dust sources, J. Geophys. Res., 104, 22243 22256, 1999.

Cwiertny, D. M., Baltrusaitis, J., Hunter, G. J., Laskin, A., Scherer, M. M., and Grassian, V. H.: Characterization and acid-mobilization study of iron-containing mineral dust source materials, J. Geophys. Res., 113, D05202, doi:10.1029/2007jd009332, 2008.

Cwiertny, D. M., Hunter, G. J., Pettibone, J. M., Scherer, M. M., and Grassian, V. H.: Surface chemistry and dissolution of $\alpha$ $\mathrm{FeOOH}$ nanorods and microrods: Environmental implications of size-dependent interactions with oxalate, J. Phys. Chem. C, 113, 2175-2186, 2009.

Deboudt, K., Gloter, A., Mussi, A., and Flament, P.: Red-ox speciation and mixing state of iron in individual African dust particles, J. Geophys. Res., 117, D12307, doi:10.1029/2011JD017298, 2012.

Deguillaume, L., Leriche, M., Desboeufs, K., Mailhot, G., George, C., and Chaumerliac, N.: Transition metals in atmospheric liquid phases: Sources, reactivity, and sensitivity parameters, Chem. Rev., 105, 3388-3431, 2005.

Desboeufs, K., Losno, R., Vimeux, F., and Cholbi, S.: pH dependent dissolution of wind transported Saharan dust, J. Geophys. Res., 104, 21287-21299, 1999.

Desboeufs, K. V., Sofikitis, A., Losno, R., Colin, J. L., and Ausset, P.: Dissolution and solubility of trace metals from natural and anthropogenic aerosol particulate matter, Chemosphere, 58, 195203, 2005.

Fan, S.-M., Horowitz, L. W., Levy II, H., and Moxim, W. J.: Impact of air pollution on wet deposition of mineral dust aerosols, Geophys. Res. Lett., 31, L02104, doi:10.1029/2003GL018501, 2004.

Fan, S.-M., Moxim, W. J., and Levy II, H.: Aeolian input of bioavailable iron to the ocean, Geophys. Res. Lett., 33, L07602, doi:10.1029/2005GL024852, 2006.

Feng, Y. and Penner, J. E.: Global modeling of nitrate and ammonium: Interaction of aerosols and tropospheric chemistry, J. Geophys. Res., 112, D01304, doi:10.1029/2005JD006404, 2007.

Formenti, P., Rajot, J. L., Desboeufs, K., Caquineau, S., Chevaillier, S., Nava, S., Gaudichet, A., Journet, E., Triquet, S., Alfaro, S., Chiari, M., Haywood, J., Coe, H., and Highwood, E.: Regional variability of the composition of mineral dust from western Africa: Results from the AMMA SOP0/DABEX and DODO field campaigns, J. Geophys. Res., 113, D00C13, doi:10.1029/2008jd009903, 2008.

Formenti, P., Schütz, L., Balkanski, Y., Desboeufs, K., Ebert, M., Kandler, K., Petzold, A., Scheuvens, D., Weinbruch, S., and Zhang, D.: Recent progress in understanding physical and 
chemical properties of African and Asian mineral dust, Atmos. Chem. Phys., 11, 8231-8256, doi:10.5194/acp-11-8231-2011, 2011.

Fu, H., Cwiertny, D. M., Carmichael, G. R., Scherer, M. M., and Grassian, V. H.: Photoreductive dissolution of Fe-containing mineral dust particles in acidic media, J. Geophys. Res., 115, D11304, doi:10.1029/2009JD012702, 2010.

Fu, H., Lin, J., Shang, G., Dong, W., Grassian, V. H., Carmichael, G. R., Li, Y., and Chen, J.: Solubility of iron from combustion source particles in acidic media linked to iron speciation, Environ. Sci. Technol., 46, 11119-11127, 2012.

Gerber, H. E.: Supersaturation and Droplet Sectral Evolution in Fog, J. Atmos. Sci., 48, 2569-2588, 1991.

Ginoux, P., Chin, M., Tegen, I., Prospero, J. M., Holben, B., Dubovik, O., and Lin, S.-J.: Sources and distributions of dust aerosols simulated with the GOCART model, J. Geophys. Res., 106, 20255-20273, 2001

Han, Q., Zender, C. S., Moore, J. K., Buck, C. S., Chen, Y., Johansen, A., and Measures, C. I.: Global estimates of mineral dust aerosol iron and aluminum solubility that account for particle size using diffusion-controlled and surfacearea-controlled approximations, Global Biogeochem. Cy., 26, GB2038, doi:10.1029/2011GB004186, 2012.

Hand, J. L., Mahowald, N. M., Chen, Y., Siefert, R. L., Luo, C., Subramaniam, A., and Fung, I.: Estimates of atmosphericprocessed soluble iron from observations and a global mineral aerosol model: Biogeochemical implications, J. Geophys. Res., 109, D17205, doi:10.1029/2004JD004574, 2004.

Herzog, M., Weisenstein, D. K., and Penner, J. E.: A dynamic aerosol module for global chemical transport models: Model description, J. Geophys. Res., 109, D18202, doi:10.1029/2003JD004405, 2004.

Hsu, S.-C., Wong, G. T. F., Gong, G.-C., Shiah, F.-K., Huang, Y.T., Kao, S.-J., Tsai, F., Lung, S.-C. C., Lin, F.-J., and Lin, I.-I.: Sources, solubility, and dry deposition of aerosol trace elements over the East China Sea, Mar. Chem., 120, 116-127, 2010.

Huneeus, N., Schulz, M., Balkanski, Y., Griesfeller, J., Prospero, J., Kinne, S., Bauer, S., Boucher, O., Chin, M., Dentener, F., Diehl, T., Easter, R., Fillmore, D., Ghan, S., Ginoux, P., Grini, A., Horowitz, L., Koch, D., Krol, M. C., Landing, W., Liu, X., Mahowald, N., Miller, R., Morcrette, J.-J., Myhre, G., Penner, J., Perlwitz, J., Stier, P., Takemura, T., and Zender, C. S.: Global dust model intercomparison in AeroCom phase I, Atmos. Chem. Phys., 11, 7781-7816, doi:10.5194/acp-11-7781-2011, 2011.

Ito, A. and Feng, Y.: Role of dust alkalinity in acid mobilization of iron, Atmos. Chem. Phys., 10, 9237-9250, doi:10.5194/acp-109237-2010, 2010.

Ito, A.: Mega fire emissions in Siberia: potential supply of bioavailable iron from forests to the ocean, Biogeosciences, 8, 16791697, doi:10.5194/bg-8-1679-2011, 2011.

Ito, A.: Contrasting the effect of iron mobilization on soluble iron deposition to the ocean in the Northern and Southern Hemispheres, J. Meteorol. Soc. Jpn., 90A, 167-188, doi:10.2151/jmsj.2012-A09, 2012.

Ito, A.: Global modeling study of potentially bioavailable iron input from shipboard aerosol sources to the ocean, Global Biogeochem. Cy., 27, 1-10, doi:10.1029/2012GB004378, 2013.

Ito, A., Kok, J., Feng, Y., and Penner, J.: Does a theoretical estimation of the dust size distribution at emission suggest more bioavailable iron deposition?, Geophys. Res. Lett., 39, L05807, doi:10.1029/2011GL050455, 2012.

Jacobson, M. Z.: Studying the effects of calcium and magnesium on size-distributed nitrate and ammonium with EQUISOLV II, Atmos. Environ., 33, 3635-3649, 1999.

Jeong, D., Kim, K., and Choi, W.: Accelerated dissolution of iron oxides in ice, Atmos. Chem. Phys., 12, 11125-11133, doi:10.5194/acp-12-11125-2012, 2012.

Journet, E., Desboeufs, K. V., Caquineau, S., and Colin, J.-L.: Mineralogy as a critical factor of dust iron solubility, Geophys. Res. Lett., 35, L07805, doi:10.1029/2007GL031589, 2008.

Johnson, M. S., Meskhidze, N., Solmon, F., Gassó, S., Chuang, P. Y., Gaiero, D. M., Yantosca, R. M., Wu, S., Wang, Y., and Carouge, C.: Modeling dust and soluble iron deposition to the South Atlantic Ocean, J. Geophys. Res., 115, D15202, doi:10.1029/2009JD013311, 2010.

Johnson, M. S. and Meskhidze, N.: Atmospheric dissolved iron deposition to the global oceans: effects of oxalate-promoted $\mathrm{Fe}$ dissolution, photochemical redox cycling, and dust mineralogy, Geosci. Model Dev., 6, 1137-1155, doi:10.5194/gmd-6-11372013, 2013.

Kandler, K., Benker, N., Bundke, U., Cuevas, E., Ebert, M., Knippertz, P., Rodríguez, S., Schütz, L., and Weinbruch, S.: Chemical composition and complex refractive index of Saharan Mineral Dust at Izaña, Tenerife (Spain) derived by electron microscopy, Atmos. Environ., 41, 8058-8074, 2007.

Kandler, K., Schutz, L., Deutscher, C., Ebert, M., Hofmann, H., Jäckel, S., Jaenicke, R., Knippertz, P., Lieke, K., Massling, A., Petzold, A., Schladitz, A.,Weinzierl, B.,Wiedensohler, A., Zorn, S., and Weinbruch, S.: Size distribution, mass concentration, chemical and mineralogical composition and derived optical parameters of the boundary layer aerosol at Tinfou, Morocco, during SAMUM 2006, Tellus B, 61, 32-50, doi:10.1111/j.16000889.2008.00385.x, 2009.

Karickhoff, S. W. and Bailey, G. W.: Optical absorption spectra of clay minerals, Clay. Clay Miner., 21, 59-70, 1973.

Kim, K., Choi, W., Hoffmann, M. R., Yoon, H. I., and Park, B. K.: Photoreductive dissolution of iron oxides trapped in ice and its environmental implications, Environ. Sci. Technol., 44, 41424148, doi:10.1021/Es9037808, 2010.

Köhler, S., Bosbach, D., and Oelkers, E. H.: Do clay mineral dissolution rates reach steady state?, Geochim. Cosmochim. Ac., 69, 1997-2006, 2005.

Kok, J. F.: A scaling theory for the size distribution of emitted dust aerosols suggests climate models underestimate the size of the global dust cycle, P. Natl. Acad. Sci. USA, 108, 1016-1021, doi:10.1073/pnas.1014798108, 2011.

Kraemer, S. M.: Iron oxide dissolution in the presence of siderophores, Aquat. Sci., 66, 3-18, 2004.

Lafon, S., Rajot, J.-L., Alfaro, S. C., and Gaudichet, A.: Quantification of iron oxides in desert aerosol, Atmos. Environ., 38, 12111218, 2004.

Lafon, S., Sokolik, I. N., Rajot, J. L., Caquineau, S., and Gaudichet, A.: Characterization of iron oxides in mineral dust aerosols: implications for light absorption, J. Geophys. Res., 111, D21207, doi:10.1029/2005jd007016, 2006.

Lanzl, C. A., Baltrusaitis, J., and Cwienty, D. M.: Dissolution of hematite nanoparticle aggregates: Influence of primary particle 
size, dissolution mechamism, and solution $\mathrm{pH}$, Langmuir, 28, 15797-15808, 2012.

Lasaga, A. C., Soler, J. M., Ganor, J., Burch, T. E., and Nagy, K. L.: Chemical-weathering rate laws and global geochemical cycles, Geochim. Cosmochim. Ac., 58, 2361-2386, 1994.

Lazaro, F. J., Gutierrez, L., Barron, V., and Gelado, M. D.: The speciation of iron in desert dust collected in Gran Canaria (Canary Islands): Combined chemical, magnetic and optical analysis, Atmos. Environ., 42, 8887-8896, doi:10.1016/j.atmosenv.2008.09.035, 2008.

Liu, H. Y., Jacob, D. J., Bey, I., and Yantosca, R. M.: Constraints from ${ }^{210} \mathrm{~Pb}$ and ${ }^{7} \mathrm{Be}$ on wet deposition and transport in a global three-dimensional chemical tracer model driven by assimilated meteorological fields, J. Geophys. Res., 106, 1210912128, 2001.

Liu, X., Penner, J. E., and Herzog, M.: Global modeling of aerosol dynamics: Model description, evaluation and interactions between sulfate and non-sulfate aerosols, J. Geophys. Res., 110, D18206, doi:10.1029/2004JD005674, 2005.

Luo, C. and Gao, Y.: Aeolian iron mobilisation by dust-acid interactions and their implications for soluble iron deposition to the ocean: a test involving potential anthropogenic organic acidic species, Environ. Chem., 7, 153-161, doi:10.1071/EN09116, 2010.

Luo, C., Mahowald, N. M., Meskhidze, N., Chen, Y., Siefert, R. L., Baker, A. R., and Johansen, A. M.: Estimation of iron solubility from observations and a global aerosol model, J. Geophys. Res., 110, D23307, doi:10.1029/2005JD006059, 2005.

Luo, C., Mahowald, N., Bond, T., Chuang, P. Y., Artaxo, P., Siefert, R., Chen, Y., and Schauer, J.: Combustion iron distribution and deposition, Global Biogeochem. Cy., 22, GB1012, doi:10.1029/2007GB002964, 2008.

Mackie, D. S., Boyd, P. W., Hunter, K. A., and McTainsh, G. H.: Simulating the cloud processing of iron in Australian dust: $\mathrm{pH}$ and dust concentration, Geophys. Res. Lett., 32, L06809, doi:10.1029/2004GL022122, 2005.

Mackie, D. S., Peat, J. M., McTainsh, G. H., Boyd, P. W., and Hunter, K. A.: Soil abrasion and eolian dust production: Implications for iron partitioning and solubility, Geochem. Geophy. Geosy., 7, Q12Q03, doi:10.1029/2006GC001404, 2006.

Mackie, D. S., Boyd, P. W. McTainsh, G. H., Tindale, N. W. Westberry, T. K., and Hunter, K. A.: Biogeochemistry of iron in Australian dust: From eolian uplift to marine uptake, Geochem. Geophy. Geosy., 9, Q03Q08, doi:10.1029/2007GC001813, 2008.

Mahowald, N. M., Engelstaedter, S., Luo, C., Sealy, A., Artaxo, P., Benitez-Nelson, C., Bonnet, S., Chen, Y., Chuang, P. Y., Cohen, D. D., Dulac, F., Herut, B., Johansen, A. M., Kubilay, N., Losno, R., Maenhaut, W., Paytan, A., Prospero, J. A., Shank, L. M., and Siefert, R. L.: Atmospheric iron deposition: Global distribution, variability, and human perturbations, Annu. Rev. Mar. Sci., 1, 245-278, 2009.

Mahowald, N.: Aerosol indirect effect on biogeochemical cycles and climate, Science, 334, 794-796, 2011.

Mehra, O. P. and Jackson M. L.: Iron oxide removal from soils and clays by a dithionite-citrate system buffered with sodium bicarbonate, Clay. Clay Miner., 7, 317-327, 1960.

Mari, C., Jacob, D. J., and Bechtold, P.: Transport and scavenging of soluble gases in a deep convective cloud, J. Geophys. Res., 105, 22255-22267, 2000.
Mermut, A. R. and Cano, A. F.: Baseline studies of the Clay Minerals Society source clays: Chemical analyses of major elements, Clay. Clay Miner., 49, 381-386, 2001.

Meskhidze, N., Chameides, W. L., Nenes, A., and Chen, G.: Iron mobilization in mineral dust: Can anthropogenic SO2 emissions affect ocean productivity?, Geophys. Res. Lett., 30, 2085, doi:10.1029/2003GL018035, 2003.

Meskhidze, N., Chameides, W. L., and Nenes, A.: Dust and pollution: A recipe for enhanced ocean fertilization?, J. Geophys. Res., 110, D03301, doi:10.1029/2004JD005082, 2005.

Morton, P. L., Landing, W. M., Shih-Chieh, H., Milne, A., AguilarIslas, A. M., Baker, A. R., Bowie, A. R., Buck, C. S., Gao, Y., Gichuki, S., Hastings, M. G., Hatta, M., Johansen, A. M., Losno, R., Mead, C., Patey, M. D., Swarr, G., Vandermark, A., and Zamora, L. M.: Methods for the sampling and analysis of marine aerosols: Results from the 2008 GEOTRACES aerosol intercalibration experiment, Limnol. Oceanogr.-Meth., 11, 62-78, 2013.

Nickovic, S., Vukovic, A., Vujadinovic, M., Djurdjevic, V., and Pejanovic, G.: Technical Note: High-resolution mineralogical database of dust-productive soils for atmospheric dust modeling, Atmos. Chem. Phys., 12, 845-855, doi:10.5194/acp-12-8452012, 2012.

Nickovic, S., Vukovic, A., and Vujadinovic, M.: Atmospheric processing of iron carried by mineral dust, Atmos. Chem. Phys., 13, 9169-9181, doi:10.5194/acp-13-9169-2013, 2013.

Oakes, M., Ingall, E. D., Lai, B., Shafer, M. M., Hays, M. D., Liu, Z. G., Russell, A. G., and Weber, R. J.: Iron solubility related to particle sulfur content in source emission and ambient fine particles, Environ. Sci. Technol., 46, 6637-6644, 2012.

Ooki, A., Nishioka, J., Ono, T., and Noriki, S.: Size dependence of iron solubility of Asian mineral dust particles, J. Geophys. ResAtmos., 114, D03202, doi:10.1029/2008JD010804, 2009.

Paris, R., Desboeufs, K. V., and Journet, E.: Variability of dust iron solubility in atmospheric waters: Investigation of the role of oxalate organic complexation, Atmos. Environ., 45, 6510-6517, 2011.

Pehkonen, S. O., Siefert, R., Erel, Y., Webb, S., and Hoffmann, M. R.: Photoreduction of iron oxyhydroxides in the presence of important atmospheric organic compounds, Environ. Sci. Technol., 27, 2056-2062, 1993.

Raiswell, R. and Canfield, D. E.: The iron biogeochemical cycle past and present, Geochem. Perspect., 1, 1-220, 2012.

Rotman, D. A., Atherton, C. S., Bergmann, D. J., Cameron-Smith, P. J., Chuang, C. C., Connell, P. S., Dignon, J. E., Franz, A., Grant, K. E., Kinnison, D. E., Molenkamp, C. R., Proctor, D. D., and Tannahill, J. R.: IMPACT, the LLNL 3-D global atmospheric chemical transport model for the combined troposphere and stratosphere: Model description and analysis of ozone and other trace gases, J. Geophys. Res., 109, D04303, doi:10.1029/2002JD003155, 2004.

Rubasinghege, G., Lentz, R. W., Scherer, M. M., and Grassian, V. H.: Simulated atmospheric processing of iron oxyhydroxide minerals at low $\mathrm{pH}$ : roles of particle size and acid anion in iron dissolution, P. Natl. Acad. Sci. USA, 107, 6628-6633, doi:10.1073/pnas.0910809107, 2010.

Schroth, A. W., Crusius, J., Sholkovitz, E. R., and Bostick, B. C.: Iron solubility driven by speciation in dust sources to the ocean, Nat. Geosci., 2, 337-340, doi:10.1038/NGEO501, 2009. 
Schulz, M., Prospero, J. M., Baker, A. R., Dentener, F., Ickes, L., Liss, P. S., Mahowald, N. M., Nickovic, S., García-Pando, C. P., Rodríguez, S., Sarin, M., Tegen, I., and Duce, R. A.: Atmospheric transport and deposition of mineral dust to the ocean: implications for research needs, Environ. Sci. Technol., 46, 1039010404, 2012.

Sedwick, P. N., Sholkovitz, E. R., and Church, T. M.: Impact of anthropogenic combustion emissions on the fractional solubility of aerosol iron: Evidence from the Sargasso Sea, Geochem. Geophy. Geosy., 8, Q10Q06 doi:10.1029/2007GC001586, 2007.

Shi, Z., Krom, M. D., Bonneville. S., Baker, A. R., Jickells, T. D., and Benning, L. G.: Formation of iron nanoparticles and increase in iron reactivity in the mineral dust during simulated cloud processing, Environ. Sci. Technol., 43, 6592-6596, doi:10.1021/es901294g, 2009.

Shi, Z., Bonneville, S., Krom, M. D., Carslaw, K. S., Jickells, T. D., Baker, A. R., and Benning, L. G.: Iron dissolution kinetics of mineral dust at low $\mathrm{pH}$ during simulated atmospheric processing, Atmos. Chem. Phys., 11, 995-1007, doi:10.5194/acp11-995-2011, 2011a.

Shi, Z., Krom, M. D., Bonneville, S., Baker, A. R., Bristow, C., Drake, N., Mann, G., Carslaw, K., McQuaid, J. B., Jickells, T., and Benning, L. G.: Influence of chemical weathering and aging of iron oxides on the potential iron solubility of Saharan dust during simulated atmospheric processing, Global Biogeochem. Cy., 25, GB2010, doi:10.1029/2010GB003837, 2011b.

Shi, Z., Krom, M. D., Jickells, T. D., Bonneville, S., Carslaw, K. S., Mihalopoulos, N., Baker, A. R., and Benning, L. G.: Impacts on iron solubility in the mineral dust by processes in the source region and the atmosphere: A review, Aeolian Research, 5, 2142, 2012.

Sholkovitz, E. R., Sedwick, P. N., Church, T. M., Baker, A. R., and Powell, C. F.: Fractional solubility of aerosol iron: Synthesis of a global-scale data set, Geochim. Cosmochim. Ac., 89, 173-189, 2012.

Sillanpää, M.: Micronutrients and the nutrient status of soils: A global study, FAO Soils Bull., 48, Food and Agric. Org. of the UN, 1982.

Sippula, O., Hokkinen, J., Puustinen, H., Yli-irilä, P., and Jokiniemi, J.: Comparison of particle emissions from small heavy fuel oil and wood-fired boilers, Atmos. Environ., 43, 4855-4864, doi:10.1016/j.atmosenv.2009.07.022, 2009.

Smetacek, V., Klaas, C., Volker, H., Strass, V. H., Assmy, P., Montresor, M., Cisewski, B., Savoye, N., Webb, A., d'Ovidio, F., Arrieta, J. M., Bathmann, U., Bellerby, R., Gry Mine Berg, G. M., Croot, P., Gonzalez, S., Henjes, J., Herndl, G. J., Hoffmann, L. J., Leach, H., Losch, M., Mills, M. M., Neill, C., Peeken, I., Röttgers, R., Sachs, O., Sauter, E., Schmidt, M. M., Schwarz, J., Terbrüggen, A., and Wolf-Gladrow, D.: Deep carbon export from a Southern Ocean iron-fertilized diatom bloom, Nature, 487, 313-319, 2012.

Solmon, F., Chuang, P. Y., Meskhidze, N., and Chen, Y.: Acidic processing of mineral dust iron by anthropogenic compounds over the north Pacific Ocean, J. Geophys. Res., 114, D02305, doi:10.1029/2008JD010417, 2009.
Song, C. H., Kim, C. M., Lee, Y. J., Carmichael, G. R., Lee, B. K., and Lee, D. S.: An evaluation of reaction probabilities of sulfate and nitrate precursors onto East Asian dust particles, J. Geophys. Res., 112, D18206, doi:10.1029/2006JD008092, 2007.

Song, Y.-C., Eom, H.-J., Jung, H.-J., Malek, M. A., Kim, H. K., Geng, H., and Ro, C.-U.: Investigation of aged Asian dust particles by the combined use of quantitative ED-EPMA and ATR-FTIR imaging, Atmos. Chem. Phys., 13, 3463-3480, doi:10.5194/acp-13-3463-2013, 2013.

Takahashi, Y., Furukawa, T., Kanai, Y., Uematsu, M., Zheng, G., and Marcus, M. A.: Seasonal changes in Fe species and soluble Fe concentration in the atmosphere in the Northwest Pacific region based on the analysis of aerosols collected in Tsukuba, Japan, Atmos. Chem. Phys., 13, 7695-7710, doi:10.5194/acp13-7695-2013, 2013.

Takahashi, Y., Higashi, M., Furukawa, T., and Mitsunobu, S.: Change of iron species and iron solubility in Asian dust during the long-range transport from western China to Japan, Atmos. Chem. Phys., 11, 11237-11252, doi:10.5194/acp-1111237-2011, 2011.

Taylor, S. R. and McLennan, S. M.: The Continental Crust: its Composition and Evolution, Blackwell Scientific, Oxford, England, 1985.

Thomson, A. M., Calvin, K. V., Smith, S. J., Kyle, G. P., Volke, A., Patel, P., Delgado-Arias, S., Bond-Lamberty, B., Wise, M. A., Clarke, L. E., and Edmonds, J. A.: RCP4.5: a pathway for stabilization of radiative forcing by 2100 , Clim. Change, 109 , 77-94, 2011.

Torrent, J., Schwertmann, U., Fechter, H., and Alferez, F.; Quantitative relationships between soil color an hematite content, Soil Sci., 136, 354-358, 1983.

Witt, M. L. I., Mather, T. A., Baker, A. R., De Hoog, J., and Pyle, D. M.: Atmospheric trace metals over the south-west Indian Ocean: Total gaseous mercury, aerosol trace metal concentrations and lead isotope ratios, Mar. Chem., 121, 2-16, 2010.

Wozniak, A. S., Shelley, R. U., Sleighter, R. L., Abdulla, H. A. N., Morton, P. L., Landing, W. M., and Hatcher, P. G.: Relationships among aerosol water soluble organic matter, iron and aluminum in European, North African, and Marine air masses from the 2010 US GEOTRACES cruise, Mar. Chem., 153, 24-33, 2013.

$\mathrm{Xu}$, L. and Penner, J. E.: Global simulations of nitrate and ammonium aerosols and their radiative effects, Atmos. Chem. Phys., 12, 9479-9504, doi:10.5194/acp-12-9479-2012, 2012.

$\mathrm{Xu}, \mathrm{N}$. and Gao, Y.: Characterization of hematite dissolution affected by oxalate coating, kinetics and $\mathrm{pH}$, Appl. Geochem., 23, 783-793, 2008

Zhang, L., Gong, S. L., Padro, J., and Barrie, L.: A size-segregated particle dry deposition scheme for an atmospheric aerosol module, Atmos. Environ., 35, 549-560, 2001.

Zhuang, G., Yi, Z., Duce, R. A., and Brown, P. R.: Link between iron and sulphur cycles suggested by detection of $\mathrm{Fe}(\mathrm{II})$ in remote marine aerosols, Nature, 355, 537-539, 1992. 